\title{
Enhancing catch-and-release science with biotelemetry
}

\author{
Michael R. Donaldson ${ }^{1}$, Robert Arlinghaus ${ }^{2}$, Kyle C. Hanson ${ }^{1}$ E Steven J. Cooke ${ }^{1}$ \\ ${ }^{1}$ Fish Ecology and Conservation Physiology Laboratory, Department of Biology, Carleton University, Ottawa, ON, Canada \\ K1S 5B6; ${ }^{2}$ Department of Biology and Ecology of Fishes, Leibniz Institute of Freshwater Ecology and Inland Fisheries, \\ 12587 Berlin, and Institute of Animal Sciences, Humboldt-University of Berlin, 10115 Berlin, Germany
}

\begin{abstract}
Catch-and-release (C\&R) angling is widely practised by anglers and is a common fisheries management strategy or is a by-product of harvest regulations. Accordingly, there is a growing body of research that examines not only the mortality associated with C\&R, but also the sublethal physiological and behavioural consequences. Biotelemetry offers a powerful means of remotely monitoring the behaviour, physiology and mortality of fish caught and released in their natural environment, but we contend that its usefulness is still underappreciated by scholars and managers. In this study, we review the applications of biotelemetry in C\&R science, identify novel research directions, opportunities and challenges. There are now about 250 C\&R studies but only one quarter of these utilize biotelemetry. In fact, almost all of the C\&R studies that have used biotelemetry have been conducted within the last decade. We found that the majority of C\&R telemetry studies used either radio or acoustic telemetry, while comparatively few studies have used satellite technologies. Most C\&R biotelemetry studies have been used to assess mortality rates, behavioural impairments or to evaluate the effects of displacement on fish. A small fraction of studies $(<8 \%)$ have used physiological sensors despite the fact that these tools are highly applicable to understanding the multiple sublethal consequences of $C \& R$ and are useful for providing mechanistic insights into endpoints such as death. We conclude that C\&R science has the potential to benefit greatly from biotelemetry technology, particularly with respect to providing more robust short-term and delayed mortality estimates and adopting a more integrative and comparative approach to understanding the lethal and sublethal impacts of C\&R. However, there are still a number of challenges including (i) the need for appropriate controls and methodological approaches, (ii) the need for accounting for tagging and handling stress and mortality, and (iii) the need for certainty in assessing mortality. However, the benefits associated with C\&R biotelemetry outweigh its disadvantages and limitations and thereby offer C\&R researchers a suite of new tools to enhance fisheries management and conservation.
\end{abstract}

Keywords Angling, biotelemetry, catch-and-release, physiological telemetry, recreational fisheries, telemetry

\author{
Correspondence: \\ Michael R. Donaldson, \\ Fish Ecology and Con- \\ servation Physiology \\ Laboratory, Depart- \\ ment of Biology, \\ Carleton University, \\ Ottawa, ON, Canada \\ K1S 5B6 \\ Tel.: + 16135202600 \\ (ext. 4377) \\ Fax: + 16135203422 \\ E-mail: mdonald2@ \\ connect.carleton.ca
}

Received 12 Jul 2007

Accepted 2 Nov 2007 


$\begin{array}{ll}\text { Applications of biotelemetry to C\&R science } & \mathbf{8 8} \\ \text { Mortality studies } & 88 \\ \text { Direct mortality studies } & 89 \\ \text { Indirect mortality studies } & 92 \\ \text { C\&R biotelemetry studies on physical condition and physiology } & \mathbf{9 2} \\ \text { Behavioural biotelemetry and C\&R } & \mathbf{9 3} \\ \text { Changes in movement following C\&R } & 93 \\ \text { C\&R tournaments and displacement } & 93 \\ \text { Migration and reproduction } & 94 \\ \text { C\&R biotelemetry and fitness } & 95 \\ \text { C\&R biotelemetry and ecosystem-level consequences } & 95 \\ \text { Experimental C\&R studies using biotelemetry } & \mathbf{9 6} \\ \text { Integrative C\&R studies using biotelemetry } & \mathbf{9 6} \\ \text { Challenges } & \mathbf{9 7} \\ \text { Directions for future research } & \mathbf{9 9} \\ \text { Conclusions } & \mathbf{1 0 0} \\ \text { Acknowledgements } & \mathbf{1 0 0} \\ \text { References } & \mathbf{1 0 1}\end{array}$

\section{Introduction}

The recreational fishing sector is considered to be a contributing factor to the decline of fish populations (Arlinghaus et al. 2002; McPhee et al. 2002; Post et al. 2002; Coleman et al. 2004; Cooke and Cowx 2004; Arlinghaus and Cooke 2005; Cooke and Cowx 2006). Multiple direct and indirect biological impacts are conceivable as a result of recreational exploitation of fish stocks (Lewin et al. 2006). Catch-and-release (C\&R) angling is a conservation approach that is becoming an increasingly used practice by anglers, either through voluntary or mandated means as a by-product of harvest regulations (Cowx 2002; Cooke and Suski 2005; Arlinghaus et al. 2007). C\&R has the potential to reduce the direct mortality associated with catchand-keep fisheries while conserving fish populations and maintaining the socioeconomic and cultural benefits of the recreational fishery (Policansky 2002; Lewin et al. 2006; Arlinghaus et al. 2007). However, C\&R as a management approach is not without its limitations and can result in undesirable biological and ecological consequences (Cooke and Suski 2005; Arlinghaus et al. 2007).

The fundamental assumption of C\&R is that released individuals will ultimately survive to contribute their genes to subsequent generations (Wydoski 1977; Cooke et al. 2002a). However, C\&R can result in immediate, short-term or delayed mortality (reviewed in Muoneke and Childress 1994; Bartholomew and Bohnsack 2005). In addition, the capture, handling and release of fish is inherently stressful and is associated with a suite of sublethal consequences, including post-release behavioural impairments and physiological responses (Cooke et al. 2002a; Cooke and Sneddon 2007; Arlinghaus et al. 2007). At a global scale, recreational fisheries exploitation rates are estimated to be as high as 47.1 billion fish per annum, two-thirds of which are released (Cooke and Cowx 2004). With such a high proportion of fish being released by the recreational fishing sector, C\&R research is becoming an increasingly important area of study, as managers demand robust scientific research to form the foundation of policy decisions and conservation efforts.

To address these concerns, the discipline of C\&R science focuses on understanding the fundamental consequences of recreational fishing on the biology and survival of released fish, including outcomes at the community and ecosystem levels (Cooke and Schramm 2007). Biotelemetry is becoming increasingly popular among C\&R researchers to study the sublethal (Cooke et al. 2002b) and lethal consequences of C\&R angling (Pollock and Pine 2007). For the purpose of this study, the definition of biotelemetry includes the remote monitoring of 
free-swimming fish in their natural environment (Cooke et al. 2004c) and also incorporates archival biologgers, which are devices that store data onboard for later downloading (Block 2005; Ropert-Coudert and Wilson 2005) or devices that initially store data and then later transmit data remotely, such as satellite transmitters (Block 2005). Although not a focus of this review, passive integrated transponder (PIT) tags can be used to identify individuals (Aalbers et al. 2004; Pope and Wilde 2004; Pope et al. 2007), allowing for the assessment of physical condition and mortality for recaptured fish and the determination of postrelease displacement and recapture rates. However, to our knowledge, PIT tags have only been used in an experimental C\&R context to identify individual fish in pens, tanks or cages. For C\&R science, biotelemetry facilitates the assessment of the behaviour, condition and fate (i.e. survival vs. mortality) of fish following release. Biotelemetry also enables the remote collection of physiological (Cooke et al. 2004a,b,c), behavioural (Nelson et al. 2005), energetic (Cooke et al. 2004a,c) and/or environmental data from free-living animals in their natural environments.

Despite its obvious advantages, biotelemetry is underused in contemporary C\&R science. Accordingly, the purpose of this review is to provide an overview and synthesis of C\&R biotelemetry. We highlight the applications and opportunities of this rapidly evolving field of study in the context of $C \& R$. The first objective of this review is to describe the current state of C\&R biotelemetry by providing a quantitative overview of the research that has been conducted to date. The second objective is to describe key applications of telemetry to understanding the biological consequences of C\&R and discuss the opportunities and challenges of using biotelemetry to study C\&R. This study presents the first quantitative review of the C\&R biotelemetry literature, summarizes key studies and provides directions for future research. It is our hope that this article will facilitate greater use of biotelemetry in C\&R research.

\section{Traditional C\&R research methods}

Historically, field-based C\&R science has been fraught with methodological challenges, as observing fish in the wild is inherently difficult and requires innovative approaches. Several methods have been used to understand the consequences of
C\&R, including external marking studies, holding pen/cage studies (Lucy and Arendt 2002; see Pollock and Pine 2007 for methodological discussion) and of late, biotelemetry. Traditional methods provide only minimal detail on the wide range of potential C\&R consequences.

Confinement studies have been used as a costeffective means of monitoring post-release condition and survival (Muoneke and Childress 1994; Whoriskey et al. 2000; Duffy 2002; Lucy and Arendt 2002), but these approaches are generally unrealistic in a C\&R context as they preclude an understanding of ecosystem interactions, such as post-release predation (Cooke and Philipp 2004; Thorstad et al. 2004), and do not allow for assessments of the fine-scale behavioural responses of free-swimming fish. Retention in pens and cages may also magnify injury, stress and mortality, potentially resulting in inaccurate assessments of mortality. In addition, confinement methods may not be practical for migratory species and/or species that require access to deep, open water, such as large pelagic fishes (Skomal 2007).

Mark-recapture studies can be useful for certain types of C\&R research questions, including longterm data collection on survival rates (Pollock and Pine 2007), as this approach is cost-effective and enables studies to have a large sample size. However, there is uncertainty, even with model calculations, that C\&R mortality estimates are accurate because of underreporting and naturally occurring mortality. This approach does not provide data on fine-scale movement behaviour which makes an assessment of behavioural impairments from C\&R very difficult. This method does not easily allow researchers to link multiple endpoints associated with C\&R, such as understanding the consequences of post-release behavioural impairments with respect to thermal habitat selection. While markrecapture studies provide very low resolution data on behaviour and mortality of a large sample size, telemetry studies provide high resolution data but generally on a smaller sample size. For mortality studies, it has been suggested by Pollock et al. (2004) that combining telemetry with markrecapture may help maximize sample size while maintaining the collection of high resolution data. Because of the challenges associated with traditional methods for studying C\&R, a growing number of researchers are using biotelemetry. Biotelemetry enables fine-scale assessments of 
behaviour, mortality and other endpoints associated with C\&R.

\section{Quantitative overview of biotelemetry in C\&R science}

Arlinghaus et al. (2007) conducted a review of the C\&R literature that had been published prior to August 2005. We updated this database using Web of Science, Google Scholar, Scholar's Portal and the American Fisheries Society search engine to survey the C\&R literature that was published from September 2005 to May 2007. A number of search strings, including 'catch and release telemetry', 'recreational fish telemetry', 'angling telemetry' and search techniques involving keywords, abstracts, full text and cited reference searches were used to maximize the number of records located. The search included peer-reviewed research articles, review articles that contained new data, graduate theses and government reports. All searching, summaries and analyses were conducted by the same researcher to ensure consistency.

In total, dating to 1957,242 C\&R studies were found, 55 (23\%) of which used biotelemetry (Table 1). The publication rate (assumed to be reflective of actual research patterns) for C\&R and biotelemetry studies has increased over time, with a marked increase in recent years. For example, 73\% of all C\&R biotelemetry studies have been published since 2000 (Fig. 1). Of these, $70 \%$ of studies were conducted on freshwater species and 30\% on marine species. This temporal trend reflects recent advancements and potentially increased affordability/awareness of telemetry technology, along with smaller size, improvements in onboard sensor technology and improved battery life (Cooke et al. 2004c). Also, fish biologists may be increasingly applying techniques that have been traditionally used in behavioural ecology to more applied research questions.

A number of biotelemetry technologies are available and have been described previously in a C\&R context (Cooke et al. 2002a; Skomal 2007). In the C\&R literature, most studies have used radio (40\%) or acoustic $(44 \%)$ transmitters. Less common technologies include electromyogram (EMG) transmitters (7\%), pop-up satellite archival tags (PSATs; 9\%) and combined acoustic and radio tags (CART; $2 \%$; Table 2). Transmitters are most commonly surgically implanted or externally attached, while gastric tagging is less common but is useful in certain contexts (e.g. anadromous migrating salmonids that are not feeding; Table 3). External attachment methods include attaching a 'backpack transmitter' that can be secured by using wires that are fed through the dorsal musculature and wound together against a backing plate to minimize scale loss and tissue damage. The attachment procedure is rapid, noninvasive and does not require fish to be anaesthetized. However, depending on the ratio of fish size to transmitter size, as well as transmitter design, colour and shape, there is potential for the backpack to increase drag and make the fish appear more conspicuous. Other external approaches have included a transmitter and float assembly (Osborne and Bettoli 1995). The assembly can be attached to a steel dart or pin which is then inserted through the dorsal musculature. If the assembly is attached using dissolvable suture material (e.g. polyglactin), it will dissolve within 3-4 weeks, which reduces the burden of the device on the fish and allows the transmitter to be recovered. As a cost-effective measure, inexpensive thermal loggers can be securely fastened to the transmitter and retrieved from the float assembly and downloaded to obtain thermal histories for individual fish. Recovery also allows for the refurbishment and redeployment of old transmitters by replacing batteries. PSATs are becoming an increasingly used technology in marine environments. Twenty-nine per cent of reviewed marine C\&R biotelemetry studies used PSATs (Table 2). PSATs are attached externally, usually via dart, log data and are then jettisoned from fish. The stored data are then transmitted by satellite link (reviewed in Brill and Lutcavage 2001). CART transmitters have only been used once in the C\&R biotelemetry literature (Young and Isley 2006). The advantages and limitations of using these different technologies are summarized in Table 4.

Over $75 \%$ of C\&R biotelemetry studies have occurred in North America $(n=42 ; 76 \%$ freshwater; $24 \%$ marine). Proportionally, freshwater studies tended to favour radio transmitters $(55 \%)$ while acoustic/ultrasonic transmitters were used most often in marine environments (71\%; Table 2). Species from the families Centrarchidae (27\%) and Salmonidae (24\%) were the most commonly studied freshwater species and Istiophoridae (15\%) and Scombridae (11\%) were the most commonly studied marine species (Table 3). Few studies have integrated multiple endpoints associated with C\&R (6\%). Overall, behaviour (73\%), mortality (69\%) and assess- 


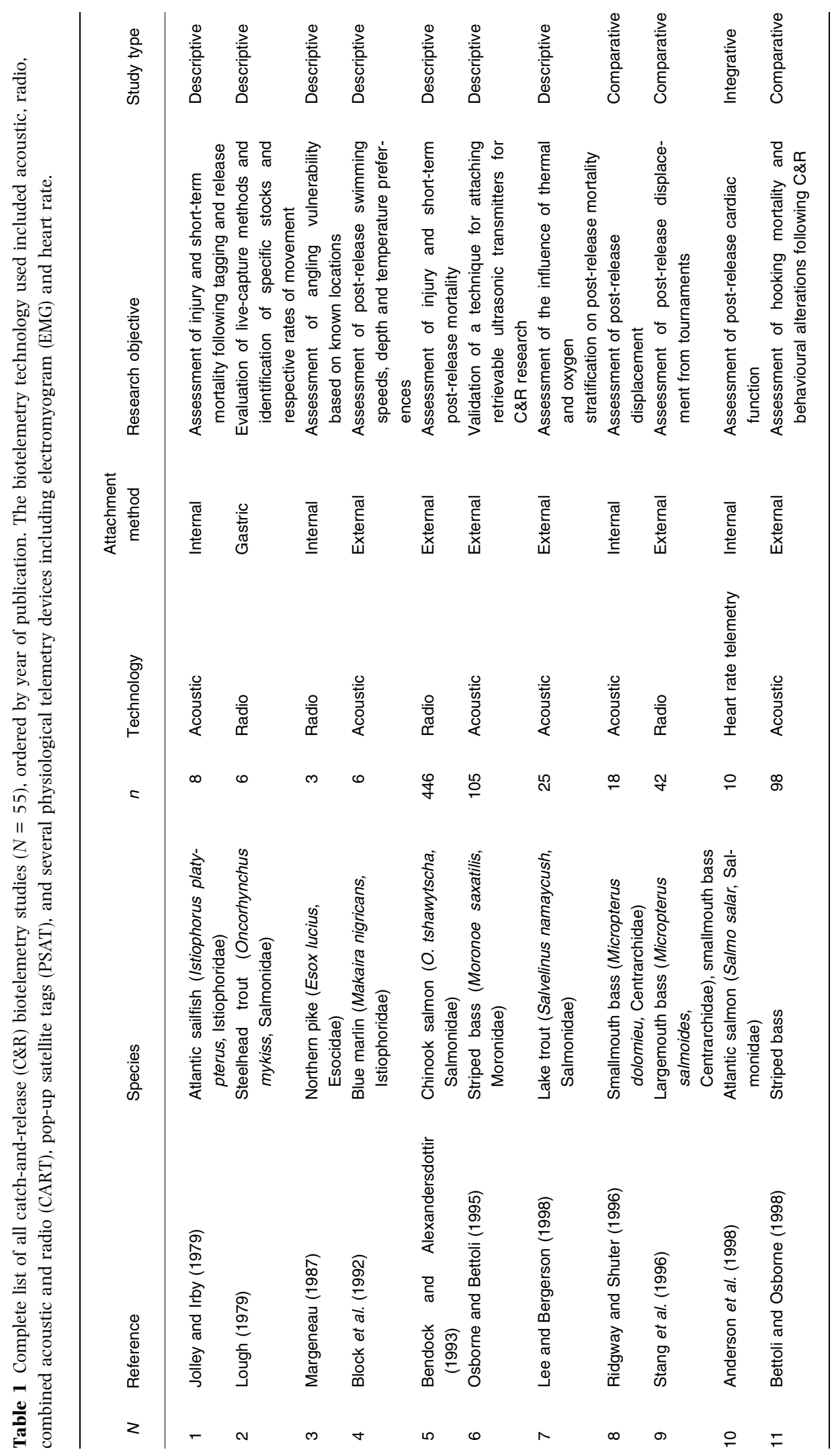

(c) 2008 The Authors

Journal compilation @ 2008 Blackwell Publishing Ltd, F ISH and F ISHER IES, 9, 79-105 


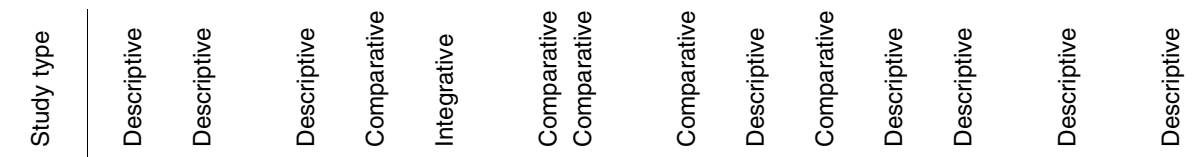

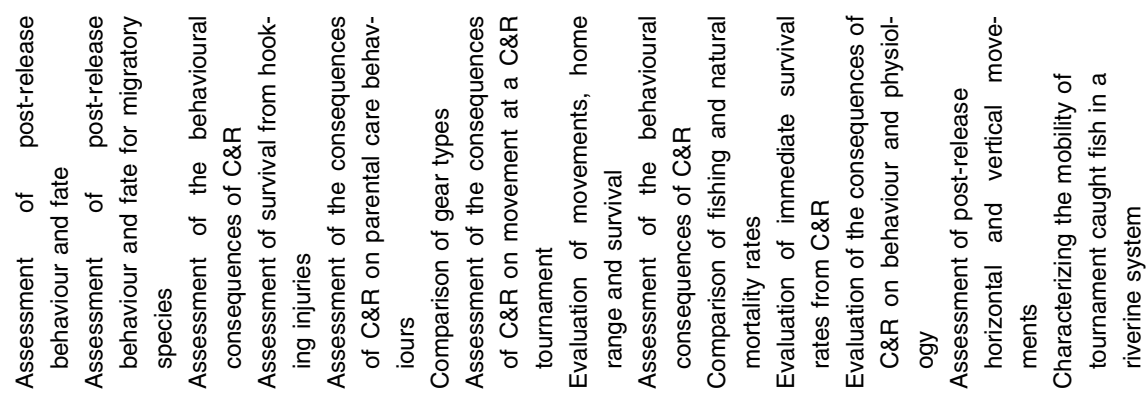

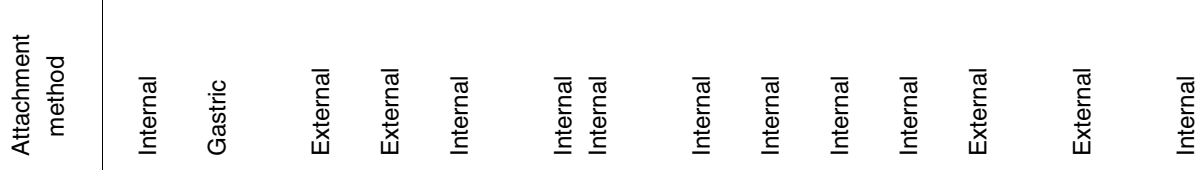

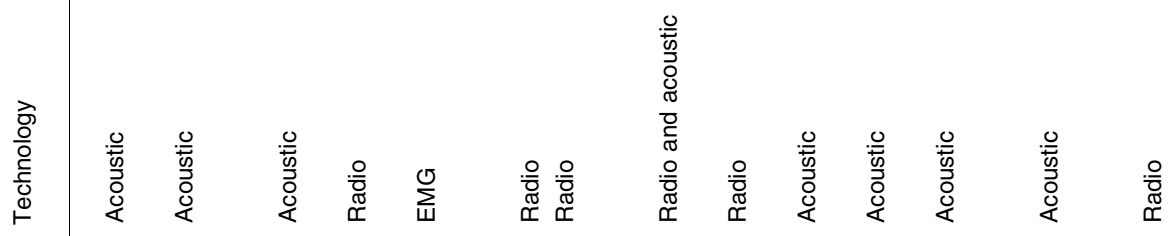

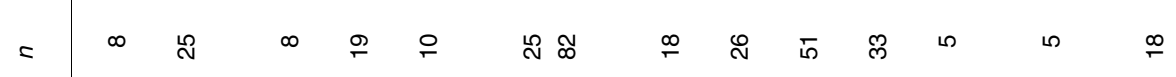

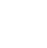




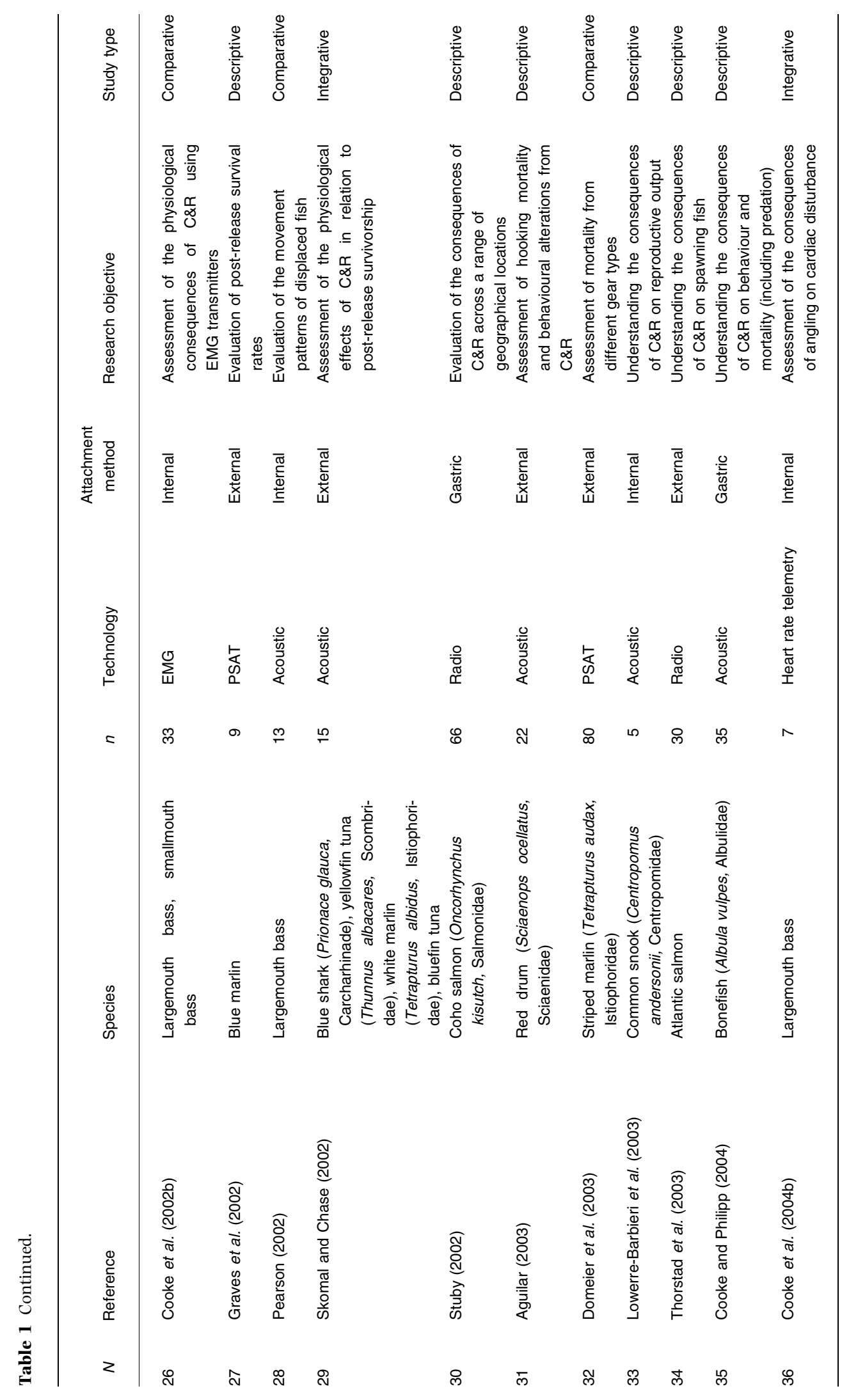

(C) 2008 The Authors

Journal compilation ( 2008 Blackwell Publishing Ltd, F ISH and F ISHER IES, 9, 79-105 


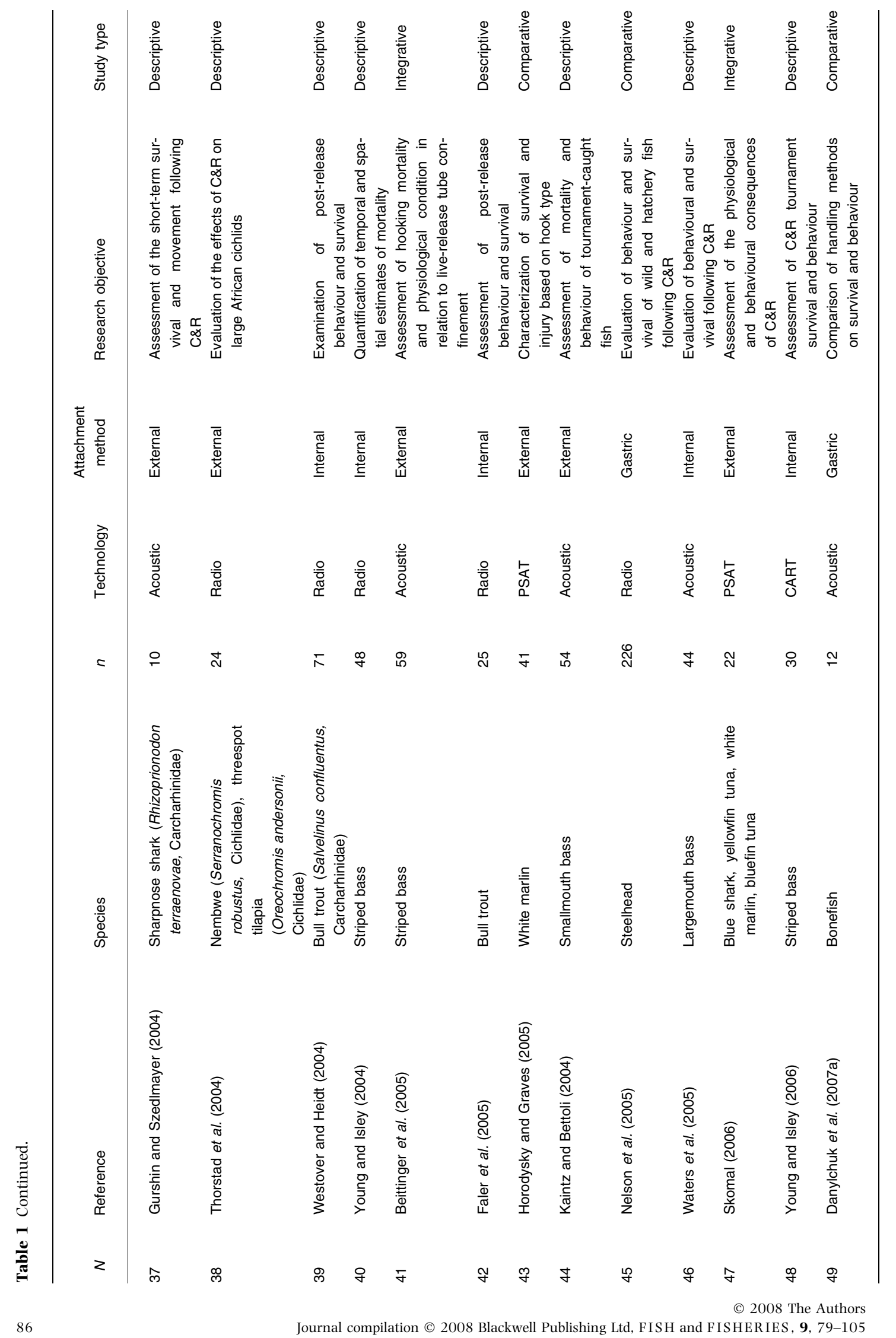




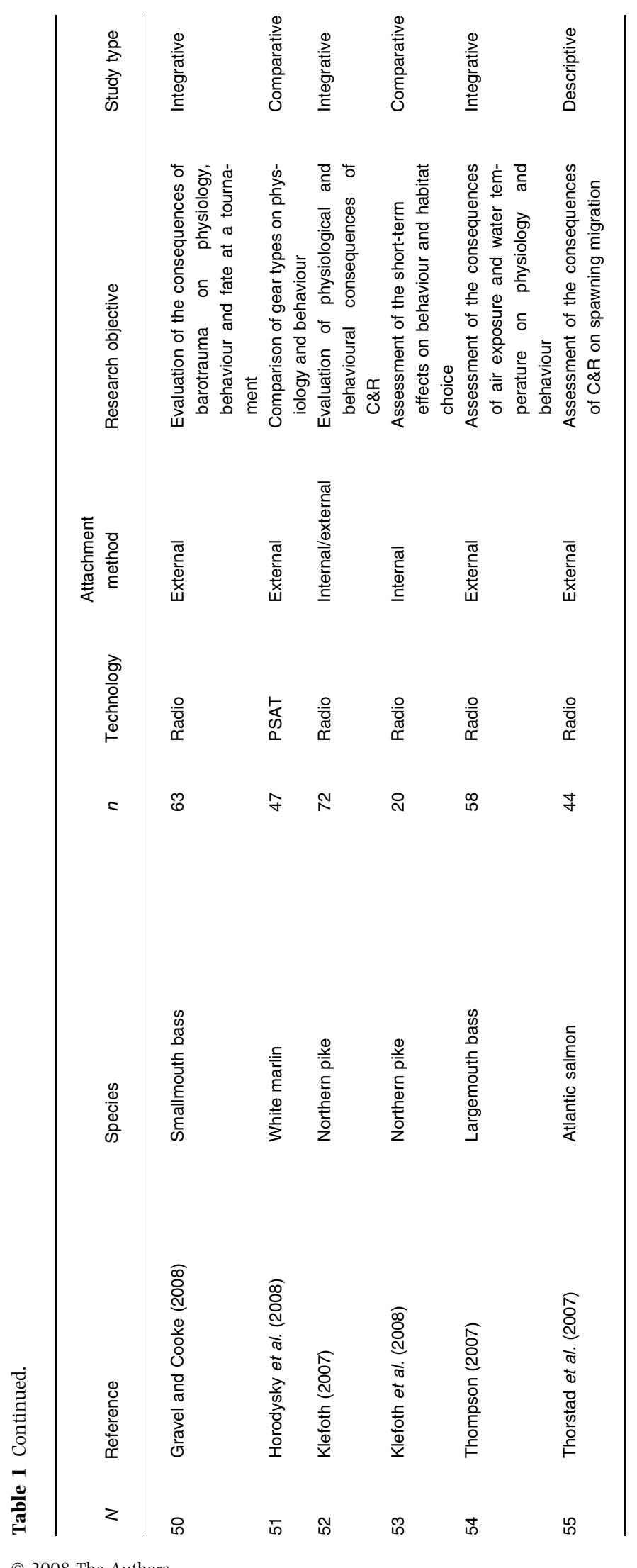

(C) 2008 The Authors

Journal compilation $\odot 2008$ Blackwell Publishing Ltd, FISH and F ISHER IES, 9, 79-105 


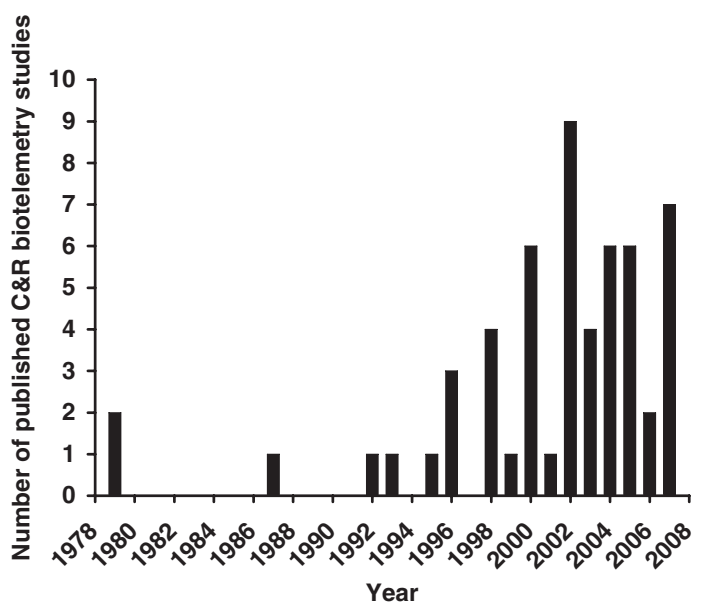

Figure 1 Number of catch-and-release (C\&R) biotelemetry studies by year.

ments of injury, gear and handling effects (35\%) were the most common endpoints measured (Table 3 ).

\section{Applications of biotelemetry to C\&R science}

\section{Mortality studies}

Despite improved knowledge of the factors that contribute to mortality, delayed mortality from C\&R is still high and has been recorded at nearly $90 \%$ for some marine and freshwater species (Muoneke and Childress 1994; Bartholomew and Bohnsack 2005). Consequently, many knowledge gaps still exist. Reducing the uncertainty surrounding mortality rates is necessary for the effective management of C\&R fisheries. Biotelemetry can be used to estimate mortality rates and can also be linked with other techniques to gain insight into the factors that contribute to mortality. Taken together, this information is required to improve the management and conservation of fish populations. However, biotelemetry alone cannot eliminate the uncertainty of the consequences of C\&R. Accordingly, we present several case studies below where biotelemetry has been used to assess mortality in a C\&R context. Within, we highlight the limitations and challenges of this approach.

Mortality is generally categorized as immediate, short term or long term. Immediate mortality is measured when a fish is dead upon landing or dies prior to or during release (Pepperell and Davis 1999). Short-term mortality may be observed within 24-48 h of an angling event, often as a result of hooking injuries in tissue or organs that result in severe blood loss immediately following release (Muoneke and Childress 1994) or elevated predation rates due to the physiological and/or behavioural impairments resulting from release (Cooke and Philipp 2004). However, delayed mortality from C\&R is often defined as mortality that occurs more than $72 \mathrm{~h}$ following the angling event (Pollock and Pine 2007). Consequently, delayed mortality is difficult to quantify and there is a high degree of uncertainty in determining mortality rates in a C\&R context. Biotelemetry is often used as a means of reducing this uncertainty. In fact, nearly $80 \%$ of the studies reviewed here used C\&R telemetry to quantify mortality (Table 3).

Determining with certainty when, or even if, a mortality event has occurred can be difficult, even with the use of biotelemetry. Transmitters with mortality sensors can be very effective at determining mortality (Eiler 1990), but the high cost of transmit-

Table 2 Number of catch-and-release angling studies that have used different transmitter types and attachment methods in freshwater and marine environments. Note that this table includes one freshwater study that used both radio and acoustic transmitters (i.e. Ridgway 2000), N/A; not applicable.

\begin{tabular}{|c|c|c|c|c|c|c|c|c|c|}
\hline \multirow[b]{2}{*}{ Transmitter type } & \multicolumn{3}{|c|}{ Freshwater } & \multicolumn{3}{|l|}{ Marine } & \multicolumn{3}{|l|}{ Total } \\
\hline & Internal & External & Gastric & Internal & External & Gastric & Internal & External & Gastric \\
\hline Radio & 9 & 9 & 4 & 0 & 0 & 0 & 9 & 9 & 4 \\
\hline Acoustic/ultrasonic & 6 & 6 & 0 & 2 & 7 & 3 & 8 & 13 & 3 \\
\hline Combined acoustic and radio & 1 & 0 & 0 & 0 & 0 & 0 & 1 & 0 & 0 \\
\hline Pop-up satellite & $N / A$ & 0 & $\mathrm{~N} / \mathrm{A}$ & $N / A$ & 5 & $\mathrm{~N} / \mathrm{A}$ & $\mathrm{N} / \mathrm{A}$ & 5 & $\mathrm{~N} / \mathrm{A}$ \\
\hline Activity/heart rate/electromyogram & 4 & 0 & $\mathrm{~N} / \mathrm{A}$ & 0 & 0 & $\mathrm{~N} / \mathrm{A}$ & 4 & 0 & $\mathrm{~N} / \mathrm{A}$ \\
\hline Total & 20 & 15 & 4 & 2 & 12 & 3 & 22 & 27 & 7 \\
\hline
\end{tabular}


Table 3 Catch-and-release (C\&R) endpoints that have been examined in studies that have used biotelemetry (by family). Studies with multiple endpoints and studies on more than one species or family of fish are recorded in the table. Note that although data are extracted from 55 studies, several studies included multiple species and endpoints.

\begin{tabular}{|c|c|c|c|c|c|c|c|c|c|}
\hline \multirow[b]{2}{*}{ Family } & \multirow[b]{2}{*}{ Species } & \multicolumn{8}{|c|}{ C\&R endpoints } \\
\hline & & Mortality & Injury & Stress & Behaviour & $\begin{array}{l}\text { Spawning } \\
\text { or migration }\end{array}$ & Fitness & $\begin{array}{l}\text { Gear or } \\
\text { handling }\end{array}$ & $\begin{array}{l}\text { Ecosystem } \\
\text { interactions }\end{array}$ \\
\hline Centrarchidae & $\begin{array}{l}\text { Largemouth bass, smallmouth } \\
\text { bass }\end{array}$ & 6 & 2 & 4 & 11 & 1 & 1 & 2 & 0 \\
\hline Salmonidae & $\begin{array}{l}\text { Atlantic salmon, } \\
\text { bull trout chinook salmon, } \\
\text { coho salmon, lake trout, } \\
\text { steelhead trout }\end{array}$ & 9 & 2 & 1 & 9 & 7 & 5 & 2 & 0 \\
\hline Istiophoridae & $\begin{array}{l}\text { Black marlin, blue marlin, } \\
\text { white marlin, striped } \\
\text { marlin, Atlantic sailfish }\end{array}$ & 5 & 3 & 2 & 5 & 0 & 0 & 1 & 0 \\
\hline Moronidae & Striped bass & 6 & 1 & 1 & 2 & 0 & 0 & 2 & 0 \\
\hline Scombridae & Bluefin tuna, yellowfin tuna & 4 & 0 & 2 & 4 & 0 & 0 & 0 & 0 \\
\hline Albulidae & Bonefish & 3 & 0 & 0 & 3 & 0 & 0 & 1 & 1 \\
\hline Carcharhinidae & $\begin{array}{l}\text { Blue shark, Atlantic } \\
\text { sharpnose shark }\end{array}$ & 3 & 0 & 2 & 3 & 0 & 0 & 0 & 0 \\
\hline Cichlidae & Nembwe, threespot tilapia & 1 & 0 & 0 & 1 & 0 & 1 & 0 & 0 \\
\hline Centropomidae & Common snook & 0 & 0 & 0 & 1 & 1 & 1 & 0 & 0 \\
\hline Esocidae & Northern pike & 2 & 1 & 1 & 2 & 0 & 0 & 2 & 0 \\
\hline Labridae & Tautog & 1 & 0 & 0 & 1 & 0 & 0 & 0 & 0 \\
\hline Percidae & Sauger & 1 & 1 & 0 & 0 & 0 & 0 & 0 & 0 \\
\hline Sciaenidae & Red drum & 1 & 0 & 0 & 1 & 0 & 0 & 1 & 0 \\
\hline \multirow{2}{*}{ Megalopidae } & Tarpon & 1 & 0 & 0 & 1 & 0 & 0 & 1 & 0 \\
\hline & Total & 43 & 10 & 13 & 44 & 9 & 8 & 12 & 1 \\
\hline
\end{tabular}

ters with sensor technology can preclude their use. As a consequence, the majority of C\&R biotelemetry studies determine mortality based on the duration of fish immobility. There are obvious flaws in this approach, as spurious conclusions can be drawn from fish that are immobile for a long period of time but may remain alive. Therefore, it is recommended that other techniques be combined with biotelemetry to further reduce the uncertainty of mortality rates. For example, if a potential mortality is identified using biotelemetry, SCUBA, snorkelling or underwater video can be used in many systems to conclusively determine fate and spurious assessments of mortality. Alternatively, there is a need for more reliable and cost-effective mortality sensors that can be incorporated into biotelemetry devices.

\section{Direct mortality studies}

Biotelemetry has been used to link mortality with hooking injury (Bendock and Alexandersdottir
1993; Bettoli et al. 2000). As with any C\&R and biotelemetry study, it is difficult to exclusively attribute mortality to only the C\&R event. A multitude of other factors may contribute to mortality, including tagging-related effects and naturally occurring (i.e. independent of the angling event) mortality. For example, Bendock and Alexandersdottir (1993) found that hooking mortality was under $8 \%$ for 446 migrating Chinook salmon (Oncorhynchus tshawytscha, Salmonidae) that were caught and released in a 3-year study on the Kenai River, Alaska. Although survival rates were relatively high in this study, mortality may have in fact been overestimated as natural mortality is often linked with difficult spawning migration of this species (Hightower et al. 2001). An alternative method would be to tag a large number of fish and recapture a random fraction of these to obtain appropriate control fish (see Klefoth et al. 2008). In closed systems with zero fishing pressure, it is possible to use telemetry to determine natural rates 


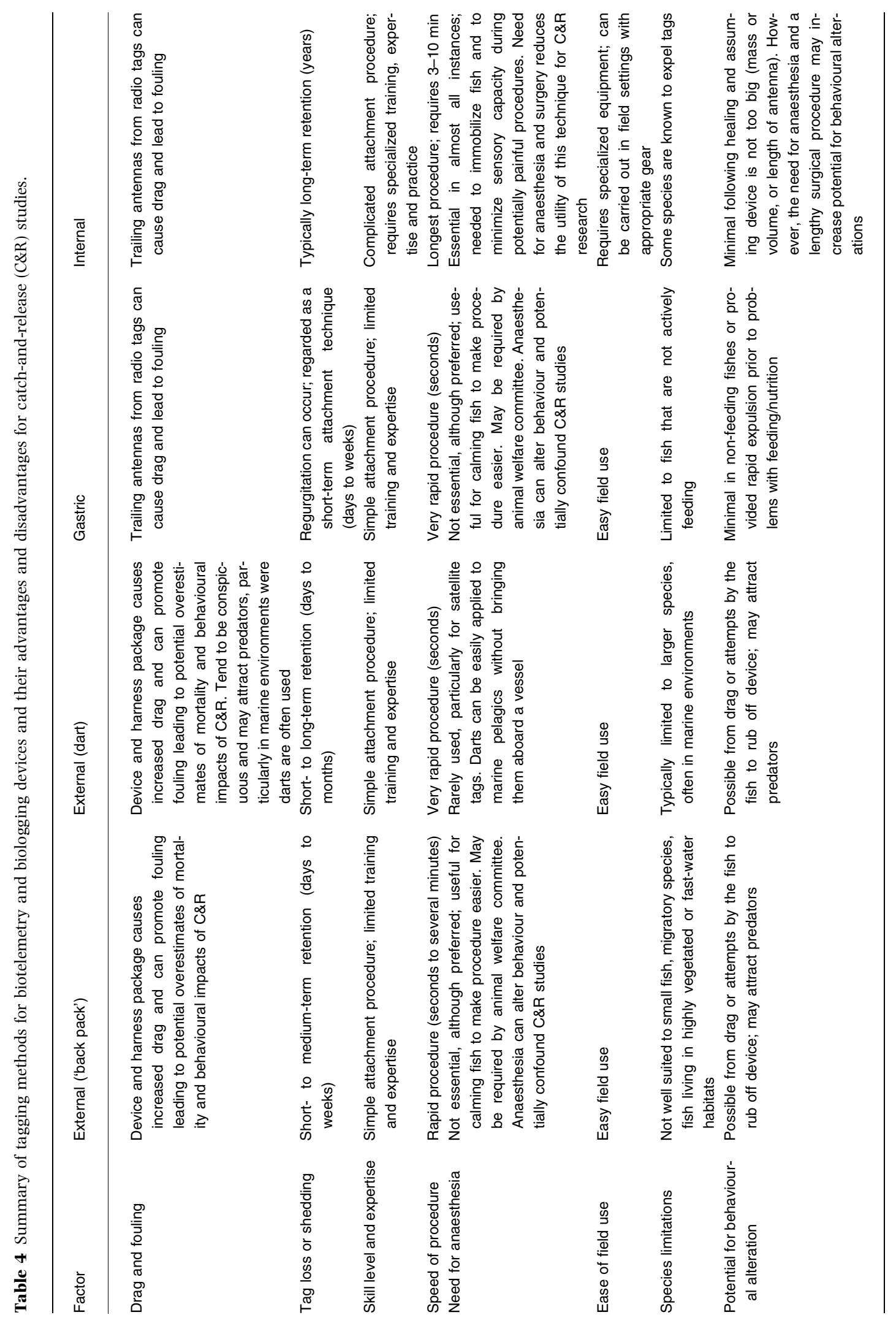


of mortality and contrasting these baseline rates to values from angling-induced mortality (Hightower et al. 2001; Waters et al. 2005). However, this is difficult in open systems because of emigration or removal from fisheries (Pollock and Pine 2007). Mortality from transmitter implantation is another potential factor that may spuriously elevate mortality rates (see 'Challenges' section below). Transmitter failure can also lead to overestimates of angler harvest.

Telemetry can be used to understand the direct and indirect factors that contribute to mortality. These factors often include environmental variables (e.g. temperature) and characteristics of the angling event (e.g. handling type, air exposure duration, gear-types). For example, Lee and Bergerson (1996) used radio telemetry to evaluate the influence of thermal and oxygen stratification on the mortality of large $(>56 \mathrm{~cm}$ ) lake trout (Salvelinus namaycush, Salmonidae) in Lake Granby, Colorado. These authors found that thermal refuge locations (sites where water temperatures were $<12{ }^{\circ} \mathrm{C}$ ) contained low dissolved oxygen $\left(3 \mathrm{mg} \mathrm{L}^{-1}\right.$ ) during 2 months in late summer. When the oxygen conditions were poor, mortality approached $88 \%$ for fish that were angled and released compared to other times of the year when mortality was less than $12 \%$ due to the availability of thermal refugia. Bettoli and Osborne (1998) found that mortality rates of angled striped bass (Morone saxatilis, Moronidae) were linearly related to air temperature, but not angling variables such as landing and handling duration, bait type, fish length or water temperature. Radio telemetry results revealed that surviving fish remained in warm surface waters for approximately $2 \mathrm{~h}$ following release and then descended into cooler and deeper waters, while fish that did not survive surfaced with $1.5 \mathrm{~h}$ due to barotrauma. This approach has also been applied in the context of marine pelagic fish. Domeier et al. (2003) used PSATs to assess the post-release survival, movement, distribution and associations with temperature and depth of striped marlin (Tetrapturus audax, Istiophoriade). The study quantified the mortality associated with J-style hooks vs. circle hooks, finding that circle hooks reduced bleeding and injury. The authors used PSAT temperature and depth data to assess mortality rates and found that mortality was high $(26 \%)$, occurring within 5 days post-release.

Pollock and Pine (2007) recently described a number of general approaches for the design and 
analysis of biotelemetry studies to assess C\&R mortality, including strategies for the accurate estimate of short-term and long-term C\&R mortality, contrasting containment vs. telemetry studies and assessments of population-level impacts of C\&R mortality. The authors concluded that in a C\&R context, biotelemetry is a useful tool for understanding mortality and the factors that contribute to mortality.

\section{Indirect mortality studies}

Biotelemetry has been used to document predation rates of fish that are caught and released, which is often linked with behavioural impairments, such as reduced fleeing potential. Following release, predation rates can be quite high, as released fish may be physiologically stressed and unable to escape from predators. This is particularly salient in marine systems where predator burdens are high but can also occur in freshwater environments from birds (Thorstad et al. 2004). In a number of studies, assessments of predator-prey interactions have not been the primary focus of the study and have instead been coincidentally documented on a small subset of tagged individuals (Jolley and Irby 1979; Block et al. 1992; Edwards 1998; Pepperell and Davis 1999; Thorstad et al. 2004; Danylchuk et al. 2007a).

Given this observational evidence it is likely that appropriately designed biotelemetry studies with larger sample sizes would document significant post-release mortality as a result of predation in systems with high predator burden. For example, Cooke and Philipp (2004) found that in an area of high shark abundance, all predation, which accounted for $39 \%$ of the total number of bonefish (Albula vulpes, Albulidae) occurred within 30 min of release. In areas of low shark abundance, no predation was observed. Mortality was associated with equilibrium loss and periods of approximately $30 \mathrm{~min}$ of immobility following the angling event. More research that specifically addresses the issue of post-release predation is required to gain a better understanding of the relative survival rates of caught-and-released fish with respect to predation.

\section{C\&R biotelemetry studies on physical condition and physiology}

In a C\&R context, fish capture generally involves hooking, netting and physical handling coupled with high anaerobic activity and air exposure. These stimuli disrupt homeostasis and elicit a physiological stress response (reviewed in Arlinghaus et al. 2007; Skomal 2007). Although the stress response is considered to be adaptive, it can result in sublethal physiological and/or behavioural impairments, or in extreme cases can lead to mortality (Arlinghaus et al. 2007). Sublethal endpoints generally include indicators of physical trauma, physiological stress, behavioural impairments, and a series of other indicators of sublethal impairments. Other sublethal indicators can include disease and pathological changes (Steeger et al. 1994; Borucinska et al. 2002), reproductive impairments (Cooke et al. 2000) and reduced growth/ energetics (Clapp and Clark 1989). In combination with a variety of techniques described below, biotelemetry is a powerful tool to assess these sublethal impacts of C\&R.

Physiological telemetry permits the remote monitoring of physiological and behavioural variables simultaneously. Previously, these measures could only be obtained in the laboratory. Despite the utility of this technology, few C\&R studies have used physiological telemetry. In fact, only two C\&R studies have used heart rate telemetry (Anderson et al. 1998; Cooke et al. 2004b) and two studies have used EMG telemetry (Cooke et al. 2000, 2002 b). Heart rate telemetry involves the placement of electrodes adjacent to the pericardial cavity to detect heart beat activity (Cooke et al. 2004a). Anderson et al. (1998) used heart rate telemetry to assess the increase in heart rate and recovery of C\&R on Atlantic salmon (Salmo salar, Salmonidae). The authors found that post-angling heart rate increased by 15-20\% across a range of temperature groups following angling. Recovery occurred within $16 \mathrm{~h}$ of release. Cooke et al. (2004b) took a similar approach by using heart rate telemetry to assess angling-induced cardiac disturbance in free-swimming largemouth bass (Micropterus salmoides, Centrarchidae). This application of heart rate telemetry allows for the reliable quantification of remote postexercise physiological activity and recovery. Cardiac output studies can provide a correlate of oxygen consumption by incorporating heart rate and stroke volume data. Unfortunately, cardiac output studies are limited to the laboratory as remote technology is not currently available to monitor cardiac output in fish (Cooke et al. 2002a).

Electromyogram telemetry provides measurement of locomotory activity and energetics of free- 
swimming fish. To date the only C\&R EMG telemetry study has been conducted on centrarchids. Cooke et al. (2000) found that largemouth bass that were angled from their nests had impaired locomotory activity $24 \mathrm{~h}$ after angling compared to non-nesting males that recovered within $2 \mathrm{~h}$ post-release. The authors concluded that the reduced activity of nesting fish following C\&R, combined with the increased predation rates of brood predators due to the short-term removal of the nest-guarding males, increases the likelihood of nest abandonment and reduces fitness. Cooke et al. (2002b) used EMG telemetry to study the crowding stress of smallmouth bass (Micropterus dolomieu, Centrarchidae) associated with livewell confinement. The authors found that when fish were held alone or with one other individual, a brief period of high activity was observed followed by low activity. When fish were introduced into livewells at densities of four or six fish, they showed heightened and variable activity during the entire retention period. Further information on C\&R and physiological telemetry can be found in two syntheses by Cooke et al. (2002a, 2004a).

The sublethal consequences of C\&R can be understood by combining behavioural data obtained from biotelemetry with other relevant sublethal endpoints, such as indicators of physiological stress. Physiological indices (e.g. stress, osmoregulatory status) can be obtained non-lethally from blood samples collected from angled fish in the wild to understand fish condition. These measures can be used as correlates of post-release mortality (Skomal 2007). Integrative studies that often combine multiple sublethal endpoints are described in more detail in the section 'Integrative C\&R studies using biotelemetry', below.

\section{Behavioural telemetry and C\&R}

\section{Changes in movement following $C \& R$}

Behavioural changes following C\&R include changes in swimming behaviour (Pepperell and Davis 1999; Klefoth et al. 2008), habitat associations (Horodysky et al. 2008; Klefoth et al. 2008) and reproductive and migratory behaviours (Cooke et al. 2000; Thorstad et al. 2003, 2007; Hanson et al. 2007). Biotelemetry can be used to assess behavioural impairments from C\&R. For example, Pepperell and Davis (1999) used acoustic telemetry to describe the post-release activity patterns, temperature associations, and diel vertical and horizontal migrations of black marlin (Makaira indica, Istiophoridae) off the Great Barrier Reef, Australia. Released fish rarely moved below the thermocline and maintained temperatures of $8^{\circ} \mathrm{C}$ below surface water temperatures. Similar studies have been conducted on white marlin (Tetrapturus albidus, Istiophoriade) (Horodysky and Graves 2005) and blue marlin (Makaira nigricans, Istiophoridae) (Graves et al. 2002) using PSATs.

Along with assessments of movement, biotelemetry can be used to assess post-release habitat associations. Horodysky et al. (2008) used PSATs to assess habitat utilization and vertical movements of white marlin that were caught and released on either commercial or recreational fishing gear. The authors found that released fish associated with surface waters less than $10 \mathrm{~m}$ deep and displayed characteristic vertical excursions from surface to depths averaging $51 \mathrm{~m}$ similar to those described by Pepperell and Davis (1999). Vertical descents followed either a distinctly v-shaped or u-shaped pattern. Similar descriptive behavioural studies have been conducted on various freshwater species (Young and Isley 2004; Thompson 2007; Klefoth et al. 2008).

\section{C\&R tournaments and displacement}

A number of studies have focused on the behaviour and survival of fish caught in live-release angling tournaments (Siepker et al. 2007). Live release fishing tournaments have been linked with mortality (Furimsky et al. 2003; Killen et al. 2003; Edwards et al. 2004), physiological stress (Suski et al. 2004), behavioural alterations (Young and Isley 2006) and barotrauma (Gravel and Cooke 2008). During tournament weigh-ins, fish are often displaced several kilometres from their initial capture locations. Biotelemetry studies have assessed post-release behaviour, the time to return to initial capture sites and overall success of returning to initial capture locations. The majority of these studies have focused on black bass tournaments (e.g. Stang et al. 1996; Richardson-Heft et al. 2000; Bunt et al. 2002; Pearson et al. 2002). The question of whether or not displaced fish subsequently return to initial capture locations allows for an understanding of whether or not live-release tournaments have negative consequences on post-release behaviour and fish distributions. Traditional approaches have included mark-recapture studies 
to assess displacement and return rates (see Traditional C\&R research methods, above). Biotelemetry allows for accurate assessments of fish movement and behaviour following release and allows for the quantification of return rates. For example, seasonal differences in return rates were observed for largemouth bass that were displaced $15-21 \mathrm{~km}$ in Chesapeake Bay. Fish released in spring tended to return within 3 months compared to fish that were released in autumn that took more than twice that time to return (Richardson-Heft et al. 2000; Wilde 2003). However, post-release movement is often unpredictable, which can result in challenges with tracking fish locations. As a consequence, movement zones are often developed in order to gauge movement and behaviour patterns (Gravel and Cooke 2008); however, this approach must be implemented objectively in order to reduce bias.

Beittinger et al. (2005) used biotelemetry to quantify the effects of hooking injury on striped bass in Lake Murray, South Carolina. Recently, the U.S. National Striped Bass Association endorsed live-release tubes, which are cylindrical recovery tanks with recirculating water, to promote survival of released striped bass, particularly at tournaments. These authors used telemetry to record behaviour and mortality and assessed the stress physiology associated with C\&R angling for a subset of fish by looking at post-capture concentrations of plasma cortisol, glucose, lactate, and osmolality to assess angling stress and subsequent holding in live-release tubes. Although this study did not specifically integrate physiological and behavioural endpoints, the notion of pairing physiological condition with post-release behaviour is relevant to understanding the shortterm consequences of C\&R (see Integrative C\&R studies using biotelemetry, below). The authors observed zero mortality during cool water temperatures in spring, but the overall mortality rate during summer was $83 \%$. Plasma cortisol, glucose, lactate and osmolality were positively related to live-release tube residence time and recovery of these indicators began after $150 \mathrm{~min}$. Young and Isley (2006) conducted a telemetry study to assess the post-release dispersal behaviour and survival of striped bass from tournament weigh-in sites. The authors found that hooking, holding, displacement and weigh-in did not adversely affect long-term behaviour.

An integrative study by Gravel and Cooke (2008) examined the physiological and behavioural consequences of tournament-caught smallmouth bass in relation to barotruama. Barotrauma occurs primarily in physoclistous species, where the swim bladder does not connect directly to the digestive tract, when fish are rapidly displaced from deep water to shallow water. Barotrauma can lead to haemorrhaging, tissue damage and swim bladder overinflation, which can lead to sublethal consequences (Hannah and Matteson 2007). Gravel and Cooke (2008) integrated both biosampling and biotelemetry techniques to link the pre-release physiological status and post-release behaviour and fate in relation to barotrauma. Non-lethal blood samples were collected to assess whole-blood concentrations of lactate and glucose and radio transmitters were externally attached to monitor post-release behaviour and fate. The concept of linking behaviour, physiology, and fate with biosampling and biotelemetry is novel for the study of the consequences of C\&R angling, but similar methods have been used in other areas of fisheries research. For example, comparable approaches have been used to understand the factors contributing to migration failure in Pacific salmonids caught in commercial purse seines (Cooke et al. 2005a) and to assess the fate of blue shark (Prionace glauca, Carcharhinidae) released as commercial longline bycatch (Moyes et al. 2006). Gravel and Cooke (in press) found that blood lactate and glucose concentrations were elevated in fish exhibiting signs of barotruama, and were highest in fish that died. Biotelemetry revealed that over $20 \%$ of the fish that showed signs of barotrauma died, while an additional 25\% were moribund within 5-6 days following release. All fish that did not show signs of barotrauma survived throughout the monitoring period. Gravel and Cooke (2008) present the first C\&R biotelemetry study to combine biosampling and biotelemetry to integrate the multiple endpoints of physiology, behaviour and fate.

\section{Migration and reproduction}

The majority of biotelemetry research on C\&R and migration has focused on adult salmonids. Anglers are easily able to target spawning migration routes because migration tends to be temporally cyclical and spatially predictable (McDowall 1999). Similarly for researchers, implementing a fixed station receiver array is often a practical solution for migrating species that follow characteristic routes and are returning to known spawning locations. 
Biotelemetry can be used to assess migratory behaviour, travel rate and mortality by using mobile tracking and/or fixed station receivers, or a combination of both methods. Tracking specific river reaches is particularly practical in systems where river length precludes simple mobile tracking (Whoriskey et al. 2000).

Catch-and-release biotelemetry allows for comparative studies to be conducted on migrants. For example, a C\&R biotelemetry study was conducted to assess the consequences of $C \& R$ on the spawning migration fate of hatchery vs. wild steelhead trout (Oncorhynchus mykiss, Salmonidae) (Nelson et al. 2005). Comparative studies based on different treatment groups are lacking for migratory species. However, assessing the consequences of different handling and air exposure treatments on postrelease migration behaviour and fate is needed for migratory species. For migration studies, C\&R biotelemetry can be used to assess short-term consequences of the angling event, for example by coupling analyses of behaviour and physiological stress (Thorstad et al. 2003) and long-term consequences, including assessments of changes in migration timing (Thorstad et al. 2007).

\section{C\&R biotelemetry and fitness}

Studying fitness can be challenging in field settings, but is of crucial importance to judge the sustainability of C\&R angling (Cooke et al. 2002a). Few studies have used C\&R biotelemetry to examine fitness. Catch-and-keep fisheries preclude harvested individuals from passing their genes to subsequent generations, while C\&R fisheries are intended to promote survival and hence fitness. However, C\&R may still have indirect fitness-level consequences due to the inherent stress associated with an angling event, which may lead to indirect fitness costs such as reduced growth (Siepker et al. 2007), reproductive output (Ostrand et al. 2004) and in extreme cases, mortality. This is particularly salient for semelparous migrants, which only have one opportunity to spawn and in the event of en route mortality, would effectively have no spawning opportunities and no chance of passing their genes to subsequent generations, effectively resulting in zero fitness.

Using comparative biotelemetry to assess the effects of C\&R on spawning behaviour and success is useful from an applied perspective to estimate the indirect fitness consequences of C\&R on individuals, and limited studies have been conducted to date. For species that engage in parental care behaviours, C\&R may result in fitness consequences through sublethal alterations in behaviour and physiology during the spawning and nest-guarding periods, as these species are particularly vulnerable to capture during the reproductive period. For example, C\&R biotelemetry revealed that nest-guarding largemouth bass that are angled from their nests will exhibit locomotory impairments for over $24 \mathrm{~h}$ following the angling event (Cooke et al. 2000). Lowerre-Barbieri et al. (2003) determined that common snook (Centropomus undecimalis, Centropomidae) that were caught and released exhibited changes in spawning behaviour, where angled individuals did not immediately leave a spawning aggregation but tended to move in and out of a spawning aggregation site more often. C\&R biotelemetry allows for basic, and commonly indirect, measurement of fitness by assessing either postrelease mortality as well as allowing for an assessment of courtship, spawning migration behaviours and spawning success following angling. Ideally, however, fitness needs to be judged by directly observing reproductive output of caughtand-release vs. control fish in the field.

\section{C\&R biotelemetry and ecosystem-level consequences}

Over-exploitation from anglers may lead to population or ecosystem-level consequences (Cooke and Cowx 2006; Lewin et al. 2006). For example, trophic cascades through the removal of key species can lead to community or ecosystem-level changes (Reynolds et al. 2002), even though C\&R theoretically reduces mortality rates, compared to catchand-keep fisheries. Little is known about how systems-level changes occur as a result of C\&R (Arlinghaus et al. 2007), largely due to the difficulty in measuring ecological outcomes. Biotelemetry alone does not allow for direct assessments of ecosystem-level consequences. However, this technology can be used in concert with other approaches to provide some understanding of the systems-level consequences of C\&R. For example, telemetry can be used to assess interspecific behavioural interactions, such as foraging behaviour and predator-prey interactions (e.g. Cooke and Philipp 2004). By combining modelling techniques with telemetry data, it would be possible to estimate overall predation rates under various conditions. 
This integrated approach could be used not only to determine when and under what circumstances a post-release predation event occurs, but also to assess the behavioural condition of the fish following capture. This is particularly useful for species that are prone to showing signs of impairment following release, such as bonefish (Cooke and Philipp 2004; Danylchuk et al. 2007b). Gaining an understanding of the ecosystem-level consequences of C\&R is obviously very difficult to obtain in practice, but remains a high priority for managers (Lewin et al. 2007).

\section{Experimental C\&R studies using biotelemetry}

Early C\&R biotelemetry studies described the movement and behaviour of fish following release, but often failed to design comparative or experimental studies with multiple treatments and controls. More recently, comparative biotelemetry approaches have been used (e.g. Thompson 2007). Comparative studies that assess relative treatment effects provide useful information to managers and C\&R tournament organizers and test the boundaries of stress resistance of fishes from a more basic scientific perspective. Comparative biotelemetry displacement studies generally compare return success and return rates by establishing a series of displacement groups at varying distances as well as one or more control groups (Richardson-Heft et al. 2000; Bunt et al. 2002). Comparative biotelemetry studies have been conducted on gear type to assess short-term survivability based on capture with J-style and circle hooks (Horodysky and Graves 2005). Nelson et al. (2005) used biotelemetry to compare the behaviour and survival of hatchery vs. wild steelhead salmon during their spawning migration. Danylchuk et al. (2007a) used biotelemetry to assess the short-term and long-term mortality associated with different handling and air exposure treatments on bonefish. In future, well-designed comparative biotelemetry studies must be conducted to ensure that results can be accurately interpreted and proper conclusions can be drawn for fisheries management.

\section{Integrative C\&R studies using biotelemetry}

Integrative C\&R studies that combine multiple endpoints, environmental conditions or intrinsic factors, such as nutritional state or genetics, are becoming more common in the fisheries research literature. Biotelemetry on its own allows for an assessment of behaviour and mortality, but when coupled with other endpoints, can provide considerable insight into the mechanisms of how C\&R affects fish biology. These assessments have often been used in the laboratory, but there are few fieldbased studies. Although laboratory studies are also very useful in this context, they often do not permit the assessment of detailed post-release condition in natural systems, which is central to the study of C\&R (Cooke and Schramm 2007). In a C\&R context, findings from laboratory and field studies are not necessarily congruent with one another. For example, Cooke et al. (2003) found that largemouth bass exposed to simulated angling treatments and monitored using heart rate telemetry had different recovery profiles in the laboratory than they did in the natural environment. Extrinsic factors including environmental condition (e.g. water temperature, dissolved oxygen), predator-prey interactions, social behaviour and movement patterns may differentially affect fish responses to angling in the wild. These discrepancies warrant more emphasis on field-based approaches to understanding C\&R consequences. Biotelemetry enables $C \& R$ researchers not only to extend laboratory-based findings to the field, but also to use telemetry tools to ask novel questions about the consequences of C\&R.

A novel application of biotelemetry to C\&R research is to link stress physiology with post-release behaviour and survivorship endpoints. Non-lethal biopsies allow for the assessment of prerelease physiological condition and biotelemetry allows for the assessment of post-release behaviour and fate (Cooke et al. 2005a; Skomal 2007). Nonlethal biosampling procedures commonly include the collection of blood samples to assess indicators of stress and exercise from plasma or whole-blood. Commonly measured endpoints include lactate, glucose, cortisol as well as changes in blood gases and $\mathrm{pH}$ and ionoregulatory status (Skomal 2007). Biopsies from other tissues can be collected nonlethally. For example, muscle tissue can be collected non-lethally and noninvasively to assess anaerobic energy stores (e.g. adenosine triphosphate, phosphocreatine and glycogen), but this technique has not yet been linked with biotelemetry in any published C\&R studies to date.

Skomal and Chase (2002) and Skomal (2006) paired stress physiology with behaviour and survi- 
vorship data from PSATs and acoustic transmitters to assess the consequences of C\&R angling on large marine pelagic fish species. The authors tested hypotheses on post-release survivorship by examining the relationship between capture indices, such as duration of angling event, and changes in blood indicators of anaerobic metabolism and muscular fatigue, including blood $\mathrm{pH}$, blood gases and lactate (reviewed in Skomal 2007). Biotelemetry results indicated that a recovery period of $2 \mathrm{~h}$ or less occurred immediately following release. Although mortality was low, Skomal and Chase (2002) and Skomal (2006) found that one bluefin tuna (Thunnus thynnus, Scrombridae) exhibited signs of severe lactacidemia and died immediately following release. However, this finding should be interpreted cautiously as two bluefin tuna that were exposed to longer angling bouts showed acid-base disruptions of a high magnitude yet survived throughout the monitoring period. Similarly, Lowe and Kelley (2004) studied the stress physiology and postrelease behaviour of caught-and-released California sheephead (Semicossyphus pulcher, Labridae). The authors found that plasma cortisol increased rapidly in proportion to the duration and intensity of handling and angling or trapping. Increases in plasma glucose, lactate (in angled fish) and insulinlike growth factor-binding protein were also observed. Acoustic telemetry data revealed that angled fish movement was limited for $12 \mathrm{~h}$ following release and no mortality occurred. However, within $18 \mathrm{~h}$, fish began to recover, although recovery time depended on the intensity of the angling event (Lowe and Kelley 2004).

In the freshwater environment, two recent case studies have taken integrative and comparative approaches to the study of C\&R by linking pre-release physiological condition with post-release behaviour and fate. Thompson (2007) combined externally attached radio transmitters and non-lethal blood sampling procedures to assess the response of largemouth bass to a range of air exposure durations and water temperatures. The author collected blood samples before and after treatment to assess changes in the concentrations of lactate, glucose, aspartate aminotransferase and $\mathrm{Na}^{+}, \mathrm{K}^{+}$and $\mathrm{Cl}^{-}$ions. Fish exposed to longer periods of air exposure had elevated plasma lactate concentrations and displayed postrelease behavioural impairments (e.g. tended to remain close to the site of release for longer durations and took longer to regain equilibrium) compared to fish exposed to shorter durations of air exposure.
Klefoth (2007) took an approach similar to that of Thompson (2007) by integrating short-term behavioural radio tracking with physiological condition for pike (Esox lucius, Esocidae) across different treatments. Treatments included exposure to various air exposure durations. Relative to controls, blood lactate levels were significantly higher in each of the treatment groups. Similar to that observed in Thompson (2007), behavioural impairments were observed in the higher duration air exposure treatments, where individuals showed significantly higher inactivity levels in the first hour after release compared to lower air exposure treatments and controls. The characteristic behavioural post-release recovery period observed in both of these studies following the C\&R event is linked with the physiological recovery of fish resulting from long or intensive angling. The recovery period is likely a response to the severe anaerobic debt acquired during the angling fight (Wood et al. 1983) as blood lactate concentrations in most cases are correlated with angling duration and intensity. In the Klefoth (2007) study, biotelemetry revealed behavioural recovery within $24 \mathrm{~h}$, similar to the results of Lowe and Kelley (2004) on California sheephead. In a C\&R context, understanding the intersection of physiological and behavioural condition is necessary to reveal how fish respond to angling stress in the wild. The case studies described above illustrate how multiple endpoints can be easily and effectively integrated to provide a more holistic understanding of the consequences of C\&R.

\section{Challenges}

The recent methodological and technological advancements of biotelemetry tools enable researchers to ask novel questions regarding the consequences of C\&R. However, biotelemetry technology itself can have many challenges associated with its use. For example, with improvements in transmitter and receiver technology, transmitter failure rates tend to be quite low, but still occur. Selecting appropriate sizes and weights can be difficult, as transmitters that are either too large or have an uneven distribution of weight may affect swimming performance and behaviour (Bettoli and Osborne 1998; Cooke et al. 2002a; Zale et al. 2005; Weimer et al. 2006). Transmitters are commercially available in a variety of sizes and weights. The traditionally followed $2 \%$ rule (i.e. $2 \%$ body weight: transmitter weight) has recently been challenged 
and it has been suggested that the lowest possible weight be used, depending on the objectives of the study and the life stages and species used (Brown et al. 1999; Jepsen et al. 2005). With all telemetry studies, there are inherent biases towards selecting fish that appear in suitable condition to carry transmitters, which is not necessarily reflective of all fish that are released in C\&R fisheries (Graves et al. 2002).

Cooke et al. (2002a) described a number of limitations associated with physiological telemetry, including challenges associated with transmitter implantation (e.g. electrode insertions in EMG surgeries). Another challenge includes the high cost of biotelemetry gear (transmitters, receivers and accessories). In many instances, particularly marine fisheries research, there are costs associated with hiring a ship and crew to deploy transmitters and/or track fish (reviewed in Skomal 2007). Cost can often be prohibitive or can limit total sample size of a study, particularly when using satellite technologies. Cost can be kept minimal when using transmitters with less sophisticated onboard sensors, although this is dependent on the research question that is being addressed in the study. In addition, there are inexpensive alternatives available, such as coupling basic positional transmitters with low-cost thermal loggers compared to costly onboard temperature sensors.

The effect of surgery or transmitter attachment on fish is one of the biggest limitations of telemetry studies (Pollock and Pine 2007). Transmitter attachment and presence can have a number of physiological and behavioural consequences (Bridger and Booth 2003) because telemetry requires the capture, handling, holding and attachment for external transmitters or insertion for gastric or surgically implanted transmitters. These processes are inherently stressful and can result in physical injury. Biotelemetry studies are based on the assumption that the implantation or attachment of transmitters does not affect fish after release. Identifying methodological vs. experimental consequences is a difficult task with biotelemetry (Jepsen et al. 2002; Bridger and Booth 2003; Cooke et al. 2004c; Wagner and Cooke 2005). Surgical insertion of transmitters requires fish to be anaesthetized and an incision to be made, which may lead to stress as well as secondary infections. Surgery effects can be minimized through practice by the surgeon. Transmitter attachment or implantation procedures should be optimized to reduce the duration of surgeries and minimize holding and handling time. Where possible, efforts should be taken to minimize scale and mucous loss as well as to maintain sterile conditions to minimize the risk of secondary infections occurring (Bauer 2005; Bauer et al. 2005; Bauer and Loupal 2007). Surgeons should ensure that trailing antennas from radio transmitters do not abrade tissue. Air exposure durations should be kept to a minimum and fish should be constantly provided with fresh, flowing water over their gills that matches environmental water temperature and dissolved oxygen conditions. In addition, optimal dosages of anaesthetics should be used (Table 4) or where possible, anaesthetics may not be necessary, such as gastric tagging (Cooke et al. 2005a). Finally, fish should be rapidly released to locations where they are sheltered from predators.

Tracking fish can be a challenge in certain systems. Where possible, a large sample size may be useful to account for tag failures, fisheries harvest, predation and other circumstances. Consideration of a telemetry array can be very useful for tracking fish that move through predictable migration routes or closed freshwater systems. However, researchers must be aware of the technological limitations of their receivers and transmitters and must design their studies accordingly. Even with the advances in biotelemetry, there are still challenges with accurately assessing mortality (Pollock and Pine 2007) and determining the cause of mortality. For example, causes of mortality can include natural mortality, C\&R consequences, surgery consequences, predation, fisheries harvest, emigration or transmitter failure (Hightower et al. 2001; Cooke and Philipp 2004; Waters et al. 2005). This can make interpretation of population-level consequences difficult for managers (Cooke and Schramm 2007). Researchers should define consistent criteria for mortality a priori for assessing mortality when tracking fish, such as defining zero movement within a certain number of days. Where possible, mortality can be confirmed using snorkelling/ SCUBA surveys in some systems. The development of improved mortality sensor technology should help mitigate this limitation. Goodyear (2002) reviewed a number of key limitations which affect C\&R mortality estimates using pop-off technology.

Designing comparative studies can be challenging, as choosing appropriate control and treatment groups is often difficult. Researchers must select ecologically relevant treatment groups that highlight 
relative effects between treatments and use caution when designing control groups. Randomly allocating treatments is necessary in experimental studies. Similarly, developing integrative studies can also be difficult. While C\&R biotelemetry permits the integration of multiple endpoints, studies that span multiple disciplines require communication amongst experts between disciplines to ensure appropriate methodologies are used. Research questions must be carefully developed in order to consider ecologically relevant endpoints and avoid autocorrelation between endpoints.

Finally, applied studies must be designed to effectively address management concerns. C\&R biotelemetry studies often fuse basic and applied science by asking fundamental research questions while also, per definition, taking an applied approach (Young and Isley 2006). These studies require communication between researchers and managers from multiple jurisdictions (i.e. regions, countries) at all stages of the study (Arlinghaus et al. 2002, 2007). Maintaining communication with anglers, managers, policy makers and where appropriate, media sources, is necessary to promote the utility of C\&R science and demonstrate the applied nature of this research.

\section{Directions for future research}

One of the major findings of this review is that the majority of C\&R biotelemetry studies (Table 3) have focused on only a few game fish species. This trend is pervasive across recreational fisheries research in general (Cooke and Suski 2005). There are many opportunities to assess the consequences of C\&R on lesser known species or species with lower economic value in many parts of the world (i.e. outside North America and Europe). Even within species, many inherent differences exist among individuals and populations which have rarely been considered in a C\&R context, such as life history, age class, size structure and sex, which could benefit from biotelemetry studies. The challenge is that many commercially and ecologically important game fish species are often found in remote regions with poor access to the resources necessary to conduct biotelemetry studies. However, as telemetry technology continues to improve (e.g. improved battery life on receiver units), and new field-based tools become available, such as the field physiology tools used by Thompson (2007), researchers have a growing number of opportu- nities to study species or populations that were previously difficult to access.

This review highlights the paucity of C\&R biotelemetry research that has assessed the ecosystemlevel consequences of C\&R. However, conservation and management efforts are increasingly leaning towards 'ecosystem-based' approaches to managing fish populations. However, in closed systems, it is possible to use a telemetry array to create an 'ecological observatory' in the field (Cooke et al. 2005b; Hanson et al. 2007). This approach would enable researchers to assess individual behavioural impairments following $\mathrm{C} \& \mathrm{R}$ in relation to ecosystem-level interactions, such as foraging behaviours, and predator-prey interactions.

Although catch-and-keep fisheries result in harvested fish effectively losing the opportunity to pass their genes on to future generations, C\&R fisheries may have fitness-level consequences that arise from stress which may lead to indirect fitness costs or indirect mortality. C\&R fisheries are implemented, at least in part, as a means of promoting survival and fitness, angling-related stressors may lead to disturbances of homeostasis. Accordingly, there are opportunities for C\&R biotelemetry research to investigate the sublethal consequences of C\&R on fitness. Understanding the fitness-level consequences of C\&R first requires an improved understanding of how fish are impaired following an angling event. This review points to the need for more integrative and comparative research to address these knowledge gaps. These types of studies will allow researchers to understand the factors that may preclude a fish from contributing their genes to subsequent generations.

A number of studies have assessed the consequences of C\&R tournaments on fish. The majority of these studies have focused on displacement and little emphasis has been placed on understanding the multiple, interactive endpoints associated with C\&R (but see Gravel and Cooke 2008), yet there are many opportunities to do so. For example, studies that assess pre- and post-release physiological condition (e.g. stress indicators) can be linked with post-release behavioural impairments and mortality at tournaments. There are logistical challenges associated with collecting data from C\&R tournaments. Coordinating with tournament organizers can sometimes be difficult, especially in large tournaments. However, tournament organizers are generally keen on the science behind C\&R and are willing to help researchers to carry out their studies. 
Similarly, tournament participants are often interested in assisting with collecting fish, which can result in large sample sizes of fish being caught in a relatively short time period.

There is considerable overlap between recreational C\&R and commercial bycatch. In both cases, fish are captured, handled, exposed to air and often held onboard for prolonged durations prior to release (Cooke and Cowx 2006; Cooke and Wilde 2007). In both fisheries, fish can be brought from depth leading to barotrauma issues (Gravel and Cooke 2008). The physiological, behavioural and survival outcomes from both fisheries sectors share many commonalities (Cooke and Cowx 2006). Accordingly, there are novel opportunities for exchanging knowledge between these two sectors. For example, Moyes et al. (2006) coupled physiological indices with PSATs to assess the consequences of bycatch release on long-term condition and survival of large marine pelagics. Similar approaches have been used in a recreational fisheries context to link stress with behaviour and survivorship (Skomal 2006; reviewed in Skomal 2007). Recently, a study was conducted to assess the post-release behaviour of white marlin following capture on either commercial longline gear or recreational rod-and-reel (Horodysky et al. 2008). Similarly, Mäkinen et al. (2000) compared the consequences of capture by gill net and by rodand-reel. Future studies need to take a more multidisciplinary approach to the design of commercial and recreational fisheries studies and take advantage of the overlap between the two sectors. C\&R and bycatch researchers should share collective knowledge and use previous research from both sectors to improve the design and implementation of future biotelemetry studies. In addition, inferences on the consequences of handling and capture stress can be made from general biotelemetry studies where fish have been captured using angling gear or comparable techniques. The general biotelemetry literature can be useful for identifying life stages or fish sizes that are more vulnerable to catch and handling stress.

\section{Conclusions}

Biotelemetry is a promising technology to aid in understanding the basic and applied aspects of $C \& R$ research. The number of C\&R biotelemetry studies is growing rapidly and studies are becoming more diverse and integrative. There are many opportu- nities for future research, particularly with respect to developing comparative and integrative studies. Improvements in biotelemetry technology, including reduced size and weight and greater functionality (i.e. temperature/depth sensors), are permitting researchers to ask novel questions and gain greater insight into the consequences of C\&R. Satellite technologies enable new data collection opportunities for comparative studies (e.g. for marine pelagic species). Integrating multiple endpoints permit the assessment of fish condition following an angling event. From both fundamental and applied perspectives, biotelemetry provides researchers and managers with an improved understanding of how fish respond to C\&R. Although there are several challenges with applying biotelemetry to $C \& R$ research, $C \& R$ fisheries science has the potential to benefit greatly from this technology. C\&R biotelemetry can provide more robust mortality estimates, permits the implementation of comparative studies, and perhaps most importantly, provides a platform for the integration of multiple C\&R endpoints. Also, it offers a tool of relevance for linking disparate scientific disciplines such as stress physiology, behavioural ecology and applied fisheries science. Finally, stakeholders are appreciating that more research on C\&R is conducted in the field under natural conditions, resulting in greater acceptance of field results among fisheries stakeholders. Biotelemetry offers a powerful means for the remote monitoring of free-swimming fish in their natural environments, but C\&R biotelemetry is only in its infancy, and there remain innumerable opportunities for future research. Although biotelemetry alone cannot provide all of the answers for fisheries management, it can be used in conjunction with traditional fisheries management approaches to provide greater insight into the consequences of C\&R.

\section{Acknowledgements}

Funding was provided by the Natural Sciences and Engineering Research Council of Canada, the Canada Foundation for Innovation, the Ontario Research Fund, Bonefish and Tarpon Unlimited, Rainy Lake Fisheries Charity Trust and Carleton University. We would like to thank M.-A. Gravel, T. Klefoth and L. Thompson for providing data summaries. Several anonymous referees provided detailed comments on earlier versions of this manuscript. 


\section{References}

Aalbers, S.A., Stutzerb, G.M. and Drawbridge, M.A. (2004) The effects of catch-and-release angling on the growth and survival of juvenile white seabass captured on offset circle and J-type hooks. North American Journal of Fisheries Management 24, 793-800.

Aguilar, R. (2003) Short-term hooking mortality and movement of adult red drum (Sciaenops ocellatus) in the Neuse River, North Carolina. PhD thesis, North Carolina State University, 138pp.

Anderson, W.G., Booth, R., Beddow, T.A., McKinley, R.S., Finstad, B., Okland, F. and Scruton, D. (1998) Remote monitoring of heart rate as a measure of recovery in angled Atlantic salmon, Salmo salar (L.). Hydrobiologia 371/372, 233-240.

Arendt, M.D. and Lucy, J.A. (2002) Intermediate-term (6 month) survival of adult tautog following catch and release, determined by ultrasonic telemetry. Catch and Release in Marine Recreational Fisheries. American Fisheries Society Symposium 30, 184-188.

Arlinghaus, R. and Cooke, S.J. (2005) Global impact of recreational fisheries. Science 307, 1561-1562.

Arlinghaus, R., Mehner, T. and Cowx, I.G. (2002) Reconciling traditional inland fisheries management and sustainability in industrialized countries, with emphasis on Europe. Fish and Fisheries 3, 261-316.

Arlinghaus, R., Cooke, S.J., Lyman, J. et al. (2007) Understanding the complexity of catch-and-release in recreational fishing: an integrative synthesis of global knowledge from historical, ethical, social, and biological perspectives. Reviews in Fisheries Science 15, 75-167.

Bartholomew, A. and Bohnsack, J.A. (2005) A review of catch-and-release angling mortality with implications for no-take reserves. Reviews in Fish Biology and Fisheries 15, 129-154.

Bauer, C. (2005) Potential problems with removing scales before surgical transmitter implantation. Journal of Fish Biology 66, 847-850.

Bauer, C. and Loupal, G. (2007) Common carp tissue reactions to surgically implanted radio tags with external antennas. Journal of Fish Biology 70, 292-297.

Bauer, C., Unfer, G. and Loupal, G. (2005) Potential problems with external trailing antennae: antenna migration and ingrowth of epithelial tissue, a case study from a recaptured Chondrostoma nasus. Journal of Fish Biology 67, 885-889.

Beittinger, J.M., Tomasso, J.R., Jr and Isely, J.J. (2005) Hooking mortality and physiological responses of striped bass angled in freshwater and held in live-release tubes. North American Journal of Fisheries Management $\mathbf{2 5}$, 1273-1280.

Bendock, T. and Alexandersdottir, M. (1993) Hooking mortality of chinook salmon released in the Kenai River, Alaska. North American Journal of Fisheries Management 13, 540-549.
Bettoli, P.W. and Osborne, R.S. (1998) Hooking mortality and behavior of striped bass following catch and release angling. North American Journal of Fisheries Management 18, 609-615.

Bettoli, P.W., Vandergoot, C.S. and Horner, P.T. (2000) Hooking mortality of saugers in the Tennessee River. North American Journal of Fisheries Management 20, 833837.

Block, B.A. (2005) Physiological ecology in the 21st century: advancements in biologging science. Integrative and Comparative Biology 45, 305-320.

Block, B.A., Booth, D.T. and Carey, E.G. (1992) Depth and temperature of the blue marlin, Makaira nigricans, observed by acoustic telemetry. Marine Biology 114, 175-183.

Borucinska, J., Kohler, N., Natanson, L. and Skomal, G. (2002) Pathology associated with retained fishing hooks in blue sharks, Prionace glauca (L.), with implications for their conservation. Journal of Fish Diseases 25, 515-521.

Bridger, C.J. and Booth, R.K. (2003) The effects of biotelemetry transmitter presence and attachment procedures on fish physiology and behavior. Reviews in Fisheries Science 11, 13-34.

Brill, R.W. and Lutcavage, M.E. (2001) Understanding environmental influences on movements and depth distributions of tunas and billfishes can significantly improve population assessments. American Fisheries Society Symposium 25, 179-198.

Brill, R., Lutcavage, M., Metzger, G., Bushnell, P., Arendt, M. and Lucy, J. (2002a) Survival of juvenile northern bluefin tuna following catch and release using ultrasonic telemetry. American Fisheries Society Symposium 30, 180-184.

Brill, R., Lutcavage, M., Metzger, G. et al. (2002b) Horizontal and vertical movements of juvenile bluefin tuna (Thunnus thynnus), in relation to oceanographic conditions of the western North Atlantic, determined with ultrasonic telemetry. Fisheries Bulletin 100, 155167.

Brown, R.S., Cooke, S.J., Anderson, W.G. and McKinley, R.S. (1999) Evidence to challenge the " $2 \%$ Rule" for biotelemetry. North American Journal of Fisheries Management 19, 867-871.

Bunt, C.M., Cooke, S.J. and Philipp, D.P. (2002) Mobility of riverine smallmouth bass related to tournament displacement and seasonal movements. Black Bass 2000: ecology, conservation and management. American Fisheries Society Symposium 31, 356-363.

Clapp, D.F. and Clark, R.D., Jr (1989) Hooking mortality of smallmouth bass caught on live minnows and artificial spinners. North American Journal of Fisheries Management 9, $81-85$.

Coleman, F.C., Figueira, W.F., Ueland, J.S. and Crowder, L.B. (2004) The impact of United States recreational fisheries on marine fish populations. Science 305, 19581960. 
Cooke, S.J. and Cowx, I.G. (2004) The role of recreational fishing in global fish crisis. Bioscience 54, 857-859.

Cooke, S.J. and Cowx, I.G. (2006) Contrasting recreational and commercial fishing: searching for common issues to promote unified conservation of fisheries resources and aquatic environments. Biological Conservation 128, 93-108.

Cooke, S.J. and Philipp, D.P. (2004) Behavior and mortality of caught-and-released bonefish (Albula spp.) in Bahamian waters with implications for a sustainable recreational fishery. Biological Conservation 118, 599607.

Cooke, S.J. and Schramm, H.L. (2007) Catch-and-release science and its application to conservation and management of recreational fisheries. Fisheries Management and Ecology 14, 73-79.

Cooke, S.J. and Sneddon, L.U. (2007) Animal welfare perspectives on recreational angling. Applied Animal Behaviour Science 104, 176-198.

Cooke, S.J. and Suski, C.D. (2005) Do we need speciesspecific guidelines for catch-and-release recreational angling to effectively conserve diverse fishery resources? Biodiversity and Conservation 14, 1195-1209.

Cooke, S.J. and Wilde, G.R. (2007) Bycatch in a recreational fisheries context. In: Bycatch Reduction in Global Fisheries (ed. S. Kennelly). Springer Academic Press, New York, pp. 181-234.

Cooke, S.J., Philipp, D.P., Schreer, J.F. and McKinley, R.S. (2000) Locomotory impairment of nesting male largemouth bass following catch-and-release angling. North American Journal of Fisheries Management 20, 968-977.

Cooke, S.J., Schreer, J.F., Dunmall, K.M. and Philipp, D.P. (2002a) Strategies for quantifying sublethal effects of marine catch-and-release angling: insights from novel freshwater applications. Catch and release in marine recreational fisheries. American Fisheries Society Symposium 30, 121-134.

Cooke, S.J., Schreer, J.F., Wahl, D.H. and Philipp, D.P. (2002b) Physiological impacts of catch-and-release angling practices on largemouth bass and smallmouth bass. American Fisheries Society Symposium 31, 489-512.

Cooke, S.J., Ostrand, K.G., Bunt, C.M., Schreer, J.F., Wahl, D.H. and Philipp, D.P. (2003) Cardiovascular responses of largemouth bass to exhaustive exercise and brief air exposure over a range of water temperatures. Transactions of the American Fisheries Society 132, 1154-1165.

Cooke, S.J., Thorstad, E.B. and Hinch, S.G. (2004a) Activity and energetics of free-swimming fish; insights from electromyogram telemetry. Fish and Fisheries 5, 21-52.

Cooke, S.J., Bunt, C.M., Ostrand, K.G., Philipp, D.P. and Wahl, D.H. (2004b) Angling-induced cardiac disturbance of free-swimming largemouth bass (Micropterus salmoides) monitored with heart rate telemetry. Journal of Applied Ichthyology 20, 28-36.
Cooke, S.J., Hinch, S.G., Wikelski, M., Andrews, R.D., Kuchel, L.J., Wolcott, T.G. and Butler, P.J. (2004c) Biotelemetry: a mechanistic approach to ecology. Trends in Ecology and Evolution 19, 334-343.

Cooke, S.J., Niezgoda, G., Hanson, K.C., Suski, C.D., Tinline, R. and Philipp, D.P. (2005a) Use of CDMA acoustic telemetry to document 3-D positions of fish: relevance to the design and monitoring of aquatic protected areas. Marine Technology Society Journal 39, 17-27.

Cooke, S.J., Crossin, G.T., Patterson, D. et al. (2005b) Coupling non-invasive physiological and energetic assessments with telemetry to understand inter-individual variation in behaviour and survivorship of sockeye salmon: development and validation of a technique. Journal of Fish Biology 67, 1342-1358.

Cowx, I.G. (2002) Recreational fisheries. In: The Fisheries Handbook (eds P. Hart and J. Reynolds), Vol. II. Blackwell Science, Oxford, pp. 367-390.

Danylchuk, A.J., Danylchuk, S.E., Cooke, S.J., Goldberg, T.L., Koppelman, J.B. and Philipp, D.P. (2007a) Postrelease mortality of bonefish, Albula vulpes, exposed to different handling practices during catch-and-release angling in Eleuthera, The Bahamas. Fisheries Management and Ecology 14, 149-154.

Danylchuk, S.E., Danylchuk, A.J., Cooke, S.J., Goldberg, T.L., Koppelman, J.B. and Philipp, D.P. (2007b) Effects of recreational angling on the post-release behavior and predation of bonefish (Albula vulpes): the role of equilibrium status at the time of release. Journal of Experimental Marine Biology and Ecology 346, 127-133.

Domeier, M.L., Dewar, H. and Nasby-Lewis, N. (2003) Mortality rate of striped marlin (Tetrapturus audax) caught with recreational tackle. Marine and Freshwater Research 54, 435-445.

Duffy, J.E. (2002) Catch-and-release mortality studies of spotted seatrout and red drum in coastal Alabama. American Fisheries Society Symposium 30, 110-113.

Edwards, R.E. (1998) Survival and movement patterns of release tarpon, Megalops atlanticus. Gulf of Mexico Science 16, 1-7.

Edwards, G.P., Neumann, R.M., Jacobs, R.B. and O'Donnell, E.B. (2004) Factors related to mortality of black bass caught during small club tournaments in Connecticut. North American Journal of Fisheries Management $\mathbf{2 4}$, 801-810.

Eiler, J.H. (1990) Radio transmitters used to study salmon in glacier rivers. American Fisheries Society Symposium $\mathbf{7}$, 364-369.

Faler, M., Mendel, G. and Fulton, C. (2005) Evaluate bull trout movements in the Tucannon and Lower Snake rivers. 2004 Annual Report, Project No. 200200600 (BPA Report DOE/BP-00009774-3), 32 pp.

Furimsky, M., Cooke, S. J., Suski, C. D., Wang, Y. and Tufts, B.L. (2003) Respiratory and circulatory responses to hypoxia in largemouth bass and smallmouth bass: 
implications for "live-release" angling tournaments. Transactions of the American Fisheries Society 132 , 1065-1075.

Goodyear, C.P. (2002) Factors affecting robust estimates of the catch-and-release mortality using pop-off tag technology. American Fisheries Society Symposium 30, 172 179.

Gravel, M.-A. and Cooke, S.J. (2008) Severity of barotrauma influences the physiological status, post-release behavior, and fate of tournament-caught smallmouth bass. North American Journal of Fisheries Management (in press).

Graves, J.E., Kerstetter, D.W., Luckhurst, B.E. and Prince, E.D. (2002) Habitat preferences of billfishes in the western North Atlantic: applicability of archival tag data to habitat-based stock assessment methodologies. ICCAT Collective Volume of Scientific Papers 55, 594602.

Gurshin, C.W.D. and Szedlmayer, S.T. (2004) Short-term survival and movements of Atlantic sharpnose sharks captured by hook-and-line in the north-east Gulf of Mexico. Journal of Fish Biology 65, 973-986.

Hannah, R.W. and Matteson, K.M. (2007) Behavior of nine species of Pacific rockfish after hook-and-line capture, recompression, and release. Transactions of the American Fisheries Society 136, 24-33.

Hanson, K.C., Cooke, S.J., Suski, C.D., Niezgoda, G., Phelan, F.J.S., Tinline, R and Philipp, D.P. (2007) Assessment of largemouth bass (Micropterus salmoides) behavior and activity at multiple spatial and temporal scales utilizing a 3-D whole-lake ecological telemetry observatory. Hydrobiologia 582, 243-256.

Hightower, J.E., Jackson, J.R. and Pollock, K.C. (2001) Use of telemetry methods to estimate natural and fishing mortality of striped bass in Lake Gaston, North Carolina. Transactions of the American Fisheries Society 130, 557567.

Horodysky, A.Z. and Graves, J.E. (2005) Application of pop-up satellite archival tag technology to estimate postrelease survival of white marlin (Tetrapturus albidus) caught on circle and straight-shank ('J') hooks in the western North Atlantic recreational fishery. Fishery Bulletin 103, 84-96.

Horodysky, A.Z., Kerstetter, D.W., Latour, R.J. and Graves, J.E. (2008) Habitat utilization and vertical movements of white marlin (Tetrapturus albidus) released from commercial and recreational fishing gears in the western North Atlantic Ocean: inferences from short-duration pop-up archival satellite tags (PSATS). Fisheries Oceanography (in press).

Jepsen, N., Koed, A., Thorstad, E.B. and Baras, E. (2002) Surgical implantation of telemetry transmitters in fish: how much have we learned? Hydrobiologia 16, 240256.

Jepsen, N., Schreck, C., Clements, S. and Thorstad, E.B. (2005) A brief discussion on the $2 \%$ tag/bodymass rule of thumb. In: Aquatic Telemetry: Advances and Applications: Proceedings of the Fifth Conference on Fish Telemetry held in Europe (eds M.T. Spedicato, G. Lembo and G. Marmulla). FAO/COISPA, Rome, pp. 255-259.

Jolley, J.W. and Irby, E.W. (1979) Survival of tagged and released Atlantic sailfish (Istiophorus platypterus: Istiophoridae) determined with acoustical telemetry. Bulletin of Marine Science 29, 155-169.

Kaintz, M.A. and Bettoli, P.W. (2004) Black Bass Tournament Activity and Initial Mortality on middle Tennessee Reservoirs. Tennessee Wildlife Resources Agency, Nashville, TN, $47 \mathrm{pp}$.

Killen, S.S., Suski, C.D., Morrisey, M.B., Dyment, P., Furimsky, M. and Tufts, B.L. (2003) Physiological responses of walleyes to live-release angling tournament. North American Journal of Fisheries Management, 23, 1238-1246.

Klefoth, T. (2007) Behaviour of pike (Esox lucius L.) in response to angler-induced disturbance in a catch-and-release fishery in Lake Kleiner Döllnsee. Master's Thesis, Humboldt-Universitat zu Berlin, Faculty of Agriculture and Horticulture, Institute of Animal Sciences Berlin, Germany, 129 pp.

Klefoth, T., Kobler, A. and Arlinghaus, R. (2008) The impact of catch-and-release angling on short term behaviour and habitat choice of northern pike (Esox lucius L.). Hydrobiologia in press.

Lee, W.C. and Bergerson, E.P. (1996) Influence of thermal and oxygen stratification on lake trout hooking mortality. North American Journal of Fisheries Management 16, 175-181.

Lewin, W.-C., Arlinghaus, R. and Mehner, T. (2007) Documented and potential biological impacts of recreational fishing: insights for management and conservation. Reviews in Fisheries Science 14, 305-367.

Lough, M.J. (1979) Radio-telemetry studies of summer run steelhead trout in the Skeena River, 1978, with particular reference to equipment and capture methods. Skeena Fisheries Report. 78-10,18 pp.

Lowe, C.G. and Kelley, K M. (2004) Catch and release of California sheephead: physiological and behavioral stress effects and post-release survival. California Sea Grant College Program Research Profiles Abstract, R/F-192.

Lowerre-Barbieri, S.K., Vose, F.E. and Whittington, A. (2003) Catch-and-release fishing on a spawning aggregation of common snook: does it affect reproductive output? Transactions of the American Fisheries Society 132, 940-952.

Lucy, J.A. and Arendt, M.D. (2002) Short-term hook release mortality in Chesapeake Bay's recreational tautog fishery. American Fisheries Society Symposium 30, 114-117.

Mäkinen, T.S., Niemelä, E., Moen, K. and Lindström, R. (2000) Effects of gill net and rod-and-reel capture on upstream migration of Atlantic salmon (Salmo salar L.) following radio tagging. Fisheries Research 45, 117 127. 
Margeneau, T.L. (1987) Vulnerability of radio-tagged northern pike to angling. North American Journal of Fisheries Management 7, 158-159.

McDowall, R.M. (1999) Different kinds of diadromy: different kinds of conservation problems. ICES Journal of Marine Science 56, 410-413.

McPhee, D.P., Leadbitter, D. and Skilletter, G.A. (2002) Swallowing the bait: is recreational fishing in Australia ecologically sustainable? Pacific Conservation Biology $\mathbf{8}$, 40-51.

Moyes, C.D., Fragoso, N., Musyl, M.K. and Brill, R.W. (2006) Predicting postrelease survival in large pelagic fish. Transactions of the American Fisheries Society 135, 1389-1397.

Muoneke, M.I. and Childress, W.M. (1994) Hooking mortality: a review for recreational fisheries. Reviews in Fisheries in Science 2, 123-156.

Nelson, T.C., Rosenau, M.L. and Johnston, N.T. (2005) Behavior and survival of wild and hatchery-origin winter steelhead spawners caught and released in a recreational fishery. North American Journal of Fisheries Management 25, 931-943.

Osborne, R. and Bettoli, P.W. (1995) A reusable ultrasonic tag and float assembly for use with large pelagic fish. North American Journal of Fisheries Management 15, 512514.

Ostrand, KG., Cooke, S.J. and Wahl, D.H. (2004) Effects of stress on largemouth bass reproduction. North American Journal of Fisheries Management 24, 1038-1045.

Pearson, J. (2002) Movements of displaced largemouth bass in two Indiana natural lakes. Lake and Reservoir Management 18, 257-262.

Pepperell, J.G. and Davis, T.L.O. (1999) Post-release behaviour of black marlin, Makaira indica, caught off Biology 135, 369-380.

Policansky, D. (2002) Catch-and-release recreational fishing: a historical perspective. In: Recreational Fisheries: Ecological, Economic and Social Evaluation (eds T.J. Pitcher and C. Hollingworth). Blackwell Science, Oxford, pp. 74-93.

Pollock, K.H. and Pine W.E., III (2007) The design and analysis of field studies to estimate catch-and-release mortality. Fisheries Management and Ecology 14, 123-130.

Pollock, K.H., Jiang, H. and Hightower, J.E. (2004) Combining radio-telemetry and fisheries tagging models to estimate fishing and natural mortality rates. Transactions of the American Fisheries Society 133, 639-648.

Pope, K.L. and Wilde, G.R. (2004) Effect of catch-and-release angling on growth of largemouth bass, Micropterus salmoides. Fisheries Management and Ecology 11, 39-44.

Pope, K.L., Wilde, G.R. and Knabe, W. (2007) Effect of catch-and-release angling on growth and survival of rainbow trout, Oncorhynchus mykiss. Fisheries Management and Ecology 14, 115-121. the Great Barrier Reef with sportfishing gear. Marine

Post, J.R., Sullivan, M., Cox, S. et al. (2002) Canada's recreational fisheries: the invisible collapse? Fisheries 27, 6-17.

Reynolds, J.D., Dulvy, N.K. and Roberts, C.R. (2002) Exploitation and other threats to fish conservation. In: Handbook of Fish Biology and Fisheries, Vol. 2 (eds P.J.B. Hart and J.D. Reynolds). Blackwell Publishing, Oxford, pp. 319-341.

Richardson-Heft, C.A., Heft, A.A., Fewlass, L. and Brandt, S.B. (2000) Movement of largemouth bass in northern Chesapeake Bay: relevance to sportfishing tournaments. North American Journal of Fisheries Management 20, 493501.

Ridgway, M.S. (2000) Movements, home range, and survival estimation of largemouth bass following displacement. American Fisheries Society Symposium 31, 525-533.

Ridgway, M.S. and Shuter, B.J. (1996) Effects of displacement on the seasonal movements and home range characteristics of smallmouth bass in Lake Opeongo. North American Journal of Fisheries Management 16, 371377.

Ropert-Coudert, Y. and Wilson, R.P. (2005) Trends and perspectives in animal-attached remote sensing. Frontiers in Ecology and the Environment 3, 437-444.

Siepker, M.J., Ostrand, K.G., Cooke, S.J., Wahl, D.H. and Philipp, D.P. (2007) A review of black bass (Micropterus spp) catch-and-release angling effects: implications for conservation and management. Fisheries Management and Ecology, 14, 91-101.

Skomal, G. (2006) The Physiological Effects of Capture Stress on Post-release Survivorship of Sharks, Tunas, and Marlin. PhD thesis, Boston University, Boston.

Skomal, G.B. (2007) Evaluating the physiological and physical consequences of capture on post-release survivorship in large pelagic fishes. Fisheries Management and Ecology 14, 81-89.

Skomal, G. and Chase, B. (2002) The physiological effects of angling on post-release surviorship in tunas, sharks, and marlin. American Fisheries Society Symposium 30, $135-138$

Stang, D.L., Green, D.M., Klindt, R.M., Chiotti, T.L. and Miller, W.E. (1996) Black bass movements after release from fishing tournaments in four New York waters. American Fisheries Society Symposium 16, 163-171.

Steeger, T.M., Grizzle, J.M., Weathers, K. and Newman, M. (1994) Bacterial diseases and mortality of angler caught largemouth bass released after tournaments on Walter F. George Reservoir, Alabama-Georgia. North American Journal of Fisheries Management 14, 435-441. Stuby, L. (2002) An Investigation of how Catch-and-Release Mortality of Coho Salmon in the Unalakleet River Varies with Distance from Norton Sound. Fishery Data Series, No 02-26. Alaska Department of Fish and Game, Division of Sport Fish, Anchorage, AK, 41 pp.

(C) 2008 The Authors 
Suski, C.D., Killen, S.S., Cooke, S.J., Kieffer, J.D., Philipp, D.P. and Tufts, B.L. (2004) Physiological significance of the weigh-in during live-release angling tournaments for largemouth bass. Transactions of the American Fisheries Society 133, 1291-1303.

Thompson, L. (2007) Linking the physiological status of largemouth bass (Micropterus salmoides) with behaviour and fate following catch-and-release angling: "airing" on the side of caution. Bachelor's thesis, Carleton University, Faculty of Environmental Science, Ottawa, ON, 30pp.

Thorstad, E.B., Naesje, T.F., Fiske, P. and Finstad, B. (2003) Effects of hook and release on Atlantic salmon in the River Alta, northern Norway. Fisheries Research 60 , 293-307.

Thorstad, E.B., Hayb, C.J., Naesje, T.F., Chanda, B. and Okland, F. (2004) Effects of catch-and-release angling on large cichlids in the subtropical Zambezi River. Fisheries Research 69, 141-144.

Thorstad, E.B., Næsje, T.F. and Leinan, I. (2007) Longterm effects of catch-and-release angling on ascending Atlantic salmon during different stages of spawning migration. Fisheries Research 85, 316-320.

Wagner, G.N. and Cooke, S.J. (2005) Methodological approaches and opinions of researchers involved in the surgical implantation of telemetry transmitters in fish. Journal of Aquatic Animal Health 17, 160-169.

Waters, D.S., Noble, R.L. and Hightower, J.E. (2005) Fishing and natural mortality of adult largemouth bass in a tropical reservoir. Transactions of the American Fisheries Society 134, 563-571.

Webb, J.H. (1998) Catch and Release: The Survival and Behaviour of Atlantic Salmon Angled and Returned to the Aberdeenshire Dee, in Spring and Early Summer. Scottish Fisheries Research Report Number ISSN 0308 (8022), 16 pp.
Weimer, E.J., Duehr, J.P. and Brown, M.L. (2006) Comparison of two external transmitter types on two sizes of bluegills and yellow perch. North American Journal of Fisheries Management 26, 670-675.

Westover, W. and Heidt, K. (2004) Upper Kootenay River bull trout radio telemetry project; monitor and protect Wigwam River bull trout for Koocanusa Reservoir, 20002003 Summary Report, Project No. 200000400, 43pp.

Whoriskey, F.G., Prusov, S. and Crabbe, S. (2000) Evaluation of the effects of catch-and-release angling on the Atlantic salmon (Salmo salar) of the Ponoi River, Kola Peninsula, Russian Federation. Ecology of Freshwater Fish 9, 118-125.

Wilde, G.R. (2003) Dispersal of tournament-caught black bass. Fisheries 28, 10-17.

Wood, C.M., Turner, J.D. and Graham, M.S. (1983) Why do fish die after severe exercise? Journal of Fish Biology 22, 189-201.

Wydoski, R.S. (1977) Relation of hooking mortality and sublethal hooking stress to quality fishery management. In: Catch-and-Release Fishing as a Management Tool (eds R.A. Barnhart and T.D. Roelofs). Humbolt State University, Arcata, CA, pp. 43-87.

Young, S.P. and Isley, J.J. (2004) Temporal and spatial estimates of adult striped bass mortality from telemetry and transmitter return data. North American Journal of Fisheries Management 24, 1112-1119.

Young, S.P. and Isley, J.J. (2006) Posttournament survival and dispersal of adult striped bass. North American Journal of Fisheries Management 26, 1030-1033.

Zale, A.V., Brooke, C. and Fraser, W.C. (2005) Effects of surgically implanted transmitter weights on growth and swimming stamina of small adult westslope cutthroat trout. Transactions of the American Fisheries Society 134, 653-660. 